\title{
Levantamento e análise da abordagem ciência, tecnologia e sociedade nas questões de biologia do ENEM de 2009 a 2014
}

Raquel Viana Raad raquelvrbio@gmail.com 0000-0001-9791-616X Universidade Federal de Minas Gerais, Belo Horizonte, Minas Gerais, Brasil.

Santer Alvares de Matos santermatos@gmail.com 0000-0002-7890-8655 Universidade Federal de Minas Gerais, Belo Horizonte, Minas Gerais, Brasil.

Francisco Ângelo Coutinho fac01@terra.com.br 0000-0003-4519-2870 Universidade Federal de Minas Gerais, Belo Horizonte, Minas Gerais, Brasil.

\begin{abstract}
RESUMO
Em 2009 surge o novo ENEM que se constitui hoje como uma das principais avaliações no cenário da educação brasileira e é entendido como uma regulador da qualidade da educação básica. Os documentos oficinais do ENEM mostram que esse exame se baseia nos conceitos de competências e habilidades, prezando, entre outras coisas, pela interdisciplinaridade, contextualização e situações-problemas. Portanto, a concepção teórica do ENEM vai ao encontro com uma abordagem Ciência-Tecnologia-Sociedade (CTS), o que é essencial para formação de um cidadão ativo e participativo. Neste trabalho identificamos, categorizamos e analisamos a abordagem CTS expressas nas questões de Biologia do ENEM de 2009 a 2014. Seguindo a metodologia de Bardin as questões foram classificadas e analisadas. Concluímos que o ENEM representa um avanço em relação aos tradicionais vestibulares, mas que ainda são necessárias modificações para que as suas questões se aproximem mais de uma abordagem CTS.
\end{abstract}

PALAVRAS-CHAVE: ENEM. Abordagem CTS. Biologia. 


\section{INTRODUÇÃO}

O Exame Nacional do Ensino Médio (ENEM) é uma avaliação de larga escala realizada anualmente desde 1998, pelo Instituto Nacional de Estudos e Pesquisas Educacionais (INEP), do Ministérios da Educação (MEC). O ENEM possui como público alvo estudantes concluintes do Ensino Médio no ano da aplicação da prova e aqueles que já o concluíram, ficando a cargo do participante, a realização do exame mais de uma vez.

Em 2009 o ENEM passou por reestruturações, sendo chamado de "novo" ENEM, sofrendo alterações na sua fundamentação teórica e metodológica e constituindo-se em uma avaliação de 180 questões - das quais 45 correspondem a Ciências da Natureza e suas Tecnologias - e uma redação, ocorrendo em dois dias. Pode-se observar que a própria organização do ENEM atual em 4 cadernos (Ciências da Natureza e suas Tecnologias; Ciências Humanas e suas Tecnologias; Linguagens, Códigos e suas Tecnologias; Matemática e suas Tecnologias) difere da organização dos vestibulares tradicionais, indicando uma tendência para uma abordagem em que as disciplinas estejam mais relacionadas (PINHEIRO; OSTERMANN, 2010). No ano de 2009 também é criado o Sistema de Seleção Unificada (SISU) para o ingresso de estudantes nas Universidades públicas do nosso país no qual os candidatos são selecionados com base nos resultados obtidos no ENEM. Assim, segundo o MEC, o ENEM tem atualmente o objetivo de "democratizar as oportunidades de acesso às vagas federais de ensino superior, possibilitar a mobilidade acadêmica e induzir a reestruturação dos currículos do ensino médio". Já Santos (2011) defende que o ENEM, desde o seu surgimento, nasceu com o propósito de ser mais do que apenas uma avaliação diagnóstica, mas surge com uma pretensão governamental para influenciar o currículo nacional.

Atualmente, em sua fundamentação teórica-metodológica o ENEM se propõem ser baseado em competências e habilidades, e na aferição de estruturas mentais complexas e não apenas na simples memorização conteudista, que embora importante em certa medida, sozinha não representa um conhecimento legítimo que nos permita conhecer processos, fenômenos e o próprio mundo em que vivemos (ALVES, 2005). Dessa forma, as provas do ENEM não devem priorizar apenas a memorização e rapidez de pensamento, mas também avaliar a capacidade dos estudantes de relacionar informações (GOMES; BORGES, 2009). $O$ ENEM é elaborado com base em uma Matriz de Referência (MR) onde estão descritas as competências e habilidades esperadas do estudante para cada área do conhecimento (BRASIL, 2009). Para a área de Ciências da Natureza e suas Tecnologias, que englobam as tradicionais disciplinas de Biologia, Química e Física, há 8 competências e 30 habilidades relacionadas (BRASIL, 2009).

Segundo Gomes \& Borges (2009), o ENEM pode ser considerado de fato uma avaliação construtivista, na qual os automatismos não são fundamentais para a resolução das questões e das situações-problemas que elas trazem. Neste sentido, - ENEM pode ser entendido como um teste que privilegia alguns processos cognitivos como resolução de problema, compreensão verbal e rapidez cognitiva, que são componentes fundamentais para a autonomia do pensamento e para a formação para o mundo do trabalho (GOMES; BORGES, 2009). Por outro lado, Maia e Justi (2008), apontam que o ENEM, quando comparado a outras avaliações internacionais de massa, apresenta poucas oportunidades do estudante explicitar o seu conhecimento devido a ter exclusivamente questões objetivas de múltipla 
escolha e, assim, esse exame ainda teria um longo caminho a percorrer e várias mudanças a serem feitas para se tornar mais investigativo.

Além disso, podemos identificar no ENEM algumas características da abordagem CTS. Apesar de ainda não se ter um consenso sobre a validade do ENEM como avaliação nacional, estudos indicam que de alguma forma as questões abordam aspectos sociocientíficos (SOBRINHO et al., 2013; ANDRELLA et al., 2011). Em relação ao ENEM de 2009 e 2010, Andrella et al. (2011), indicam que o exame é claramente baseado em pressupostos CTS e que a sua Matriz de Referência apresenta aspectos CTS em todas as suas 8 competências embora elas sejam trabalhadas em apenas algumas questões. Ainda não há delimitações do enfoque CTS no campo educacional, no entanto há três dimensões interdependentes que podem ser utilizadas para caracterizar o CTS no contexto brasileiro: a abordagem de temas de relevância social, a interdisciplinaridade e tomada de decisão em tema envolvendo Ciência-Tecnologia (AULER, 2007). Essas três dimensões podem ser identificadas nas questões do ENEM, uma vez que segundo o INEP o exame preza pela interdisciplinaridade, pela contextualização e pela resolução de situaçõesproblemas que levem a tomada de decisão. Além disso, a Matriz de Referência para Ciências da Natureza e suas Tecnologias apresentam todas as suas 8 competências voltadas para um enfoque CTS (BRASIL, 2009; ANDRELLA et al., 2011).

O ENEM, portanto, passou por profundas modificações deste o seu surgimento até os dias atuais, e é hoje uma das principais avaliações no cenário da educação brasileira, podendo ser entendido como um regulador da qualidade da educação básica. Com a adoção do chamado novo ENEM em 2009 o número de inscritos aumentou muito e esse exame ganhou importância no planejamento pedagógico, que antes era ditado pelo vestibular tradicional (SAPATINI, 2014). Por exemplo, na sua primeira edição em caráter opcional calcula-se que apenas $10 \%$ dos estudantes concluintes do Ensino Médio tenham optado por se inscrever na avaliação (SANTOS, 2011). Assim, em 1998, a quantidade de inscritos era de 160.000 enquanto na edição de 2012 esse número sobe para 5,79 milhões (INEP, 2015). Além disso, um número cada vez maior de instituições de ensino superior vem utilizando o ENEM nos seus processos seletivos, de forma complementar ou de forma substituta, o que nos revela que em cada edição esse exame vem aumentando a sua credibilidade junto as Instituições de Ensino Superior (IES) do país (BRASIL, 2002). Além disso, vem aumentando também o número de trabalhos acadêmicos que se dedicam ao estudo do ENEM. Jaloto e Martins (2013) apontam que entre 2007 e 2011 houve um aumento do número de trabalhos do Encontro Nacional de Pesquisa em Educação de Ciências (ENPEC) que tem como objeto de estudo o ENEM.

O ENEM tem um papel fundamental na implementação da Reforma do Ensino Médio e ao apresentar na sua prova itens que prezam pela interdisciplinaridade, contextualização e situação problema - componentes cognitivos pouco trabalhados na comunidade escolar - indica aquilo que se espera dos alunos que concluem o ensino médio (ALVES, 2005). Portanto, espera-se que o novo ENEM, por ser um método de seleção para o Ensino Superior, influencie também no currículo escolar (BEBER, 2012; SOBRINHO et al., 2013).

Diante do exposto, neste trabalho, analisamos em que medida as questões de Biologia, presente no caderno de Ciências da Natureza do ENEM, de 2009 a 2014, se aproximam de uma abordagem CTS, tendo em vista que esse exame foi 
reformulado em 2009. Assim, os objetivos desse trabalho foram identificar, categorizar e analisar a abordagem CTS expressa nas questões de Biologia presentes no ENEM de 2009 a 2014.

\section{O MOVIMENTO CTS NO MUNDO E NO BRASIL}

Segundo Garcia et al. (1996), o movimento Ciência, Tecnologia e Sociedade (CTS) surgiu em meados do século XX em países da América do Norte e Europa. Esse movimento aparece como uma resposta em relação a concepção tradicional de Ciências e da Tecnologia, aos problemas políticos e econômicos diante da percepção que os desenvolvimentos tecnológicos e científicos não conduziam necessariamente ao bem-estar social ou melhoria das condições de vida (GARCIA et al., 1996). O movimento CTS busca discutir a Ciência, Tecnologia e Sociedade e entender como eles se relacionam, permitindo uma maior compreensão sobre esses aspectos (STRIEDER, 2012). Portanto, o movimento surge como um questionamento da suposta neutralidade da ciência e do modelo tecnocrático - no qual apenas o especialista tem condição de decidir sobre questões sociais, da ciência e tecnologia - e indo em direção ao debate político (ROSA; AULER, 2013).

Santos (1992), em seu trabalho evidencia que o ensino utilizando a abordagem CTS pode ser sintetizado na figura a seguir, extraída de Hofstein et al. (1988):

Figura 1 - Inter-relações entre Ciências, Tecnologia e Sociedade.

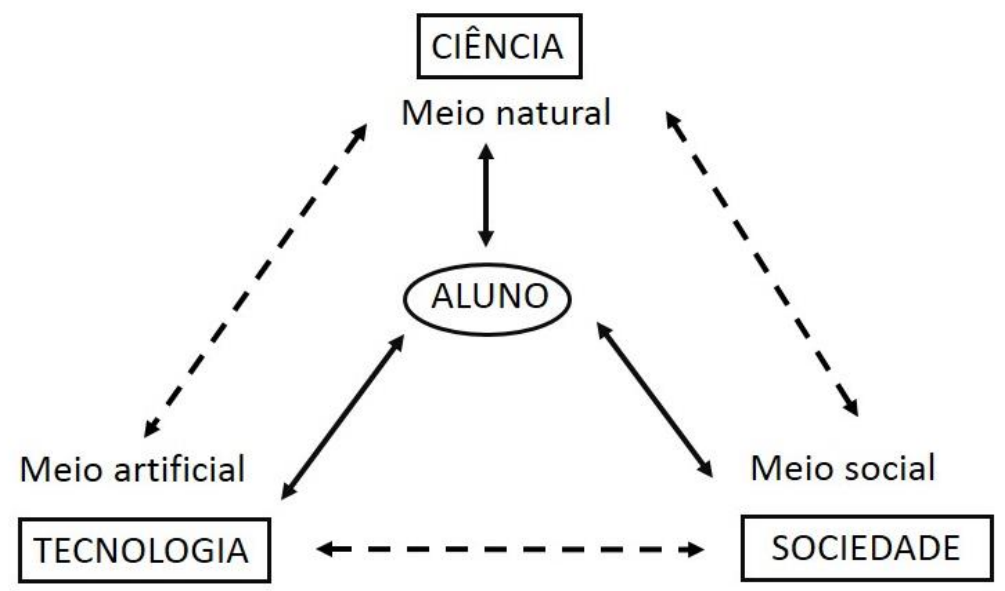

(Fonte: Gallagher, 1971; Santos, 1992)

Na Figura 1 pode-se observar que a Ciência representa o meio natural, a maneira que intuitivamente e de forma pessoal os alunos conseguem entender e interpretar o mundo em que se vive (GALLAGHER, 1971; SANTOS, 1992). Esse meio natural se comunica com outros dois meios que são o meio artificial e o meio social (GALLAGHER, 1971; SANTOS, 1992). O meio artificial compreende a tecnologia que é criada pelo ser humano e o meio social é compreendido como a sociedade e as vivências diárias que fazem parte do cotidiano do aluno (GALLAGHER, 1971; SANTOS, 1992). As setas contínuas representam o entendimento do aluno, enxergando ciência, tecnologia e sociedade como peças separadas e isoladas (GALLAGHER, 1971; SANTOS, 1992). Já as setas tracejadas representam o que se pretende com o ensino CTS, em que, com o intermédio do professor, há a conexão 
entre Ciências, Tecnologia e Sociedade, permitindo uma melhor compreensão do mundo e uma visão mais global e integrada (GALLAGHER, 1971; SANTOS, 1992). Sendo assim, a Ciência contribuiria com o ensino numa abordagem CTS demonstrando que não há verdades absolutas e que a ciência lida com informações e verdades provisórias (GALLAGHER, 1971; SANTOS, 1992). A tecnologia, por sua vez, contribuiria, por exemplo, mostrando de que forma o conhecimento pode ser trabalhado para atender a demandas sociais (GALLAGHER, 1971; SANTOS, 1992). Por fim, no aspecto da sociedade, a abordagem CTS contribui para que os alunos se percebam como cidadãos ativos e que tem poder de influência na sociedade e em decisões de cunho científico e tecnológico (GALLAGHER, 1971; SANTOS, 1992). Nessa perspectiva, Gallagher (1971) destaca, em um dos primeiros artigos publicados sobre CTS que em uma sociedade democrática de fato, a preocupação em se compreender as inter-relações e conexões entre Ciências, Tecnologia e Sociedade deve ser tão importante quanto compreender os próprios processos e fenômenos da Ciências (GALLAGHER, 1971).

Inicialmente, o movimento CTS foi classificado em duas vertentes de acordo com as suas origens e principais características: a tradição europeia ou acadêmica e a tradição norte-americana ou social (GARCIA et al., 1996). Apesar dessa divisão inicial que teve um papel importante para o início das discussões, essa dicotomia atualmente está superada, pois há um movimento único com pontos em comum, como, a superação da visão das ciências como atividade neutra e pura, o estimulo a participação pública na tomada de decisões e a superação da concepção de que a tecnologia é a ciência aplicada (GARCIA et al., 1996; STRIEDER, 2012).

Na América Latina surgiu o Pensamento Latino Americano em CTS (PLACTS) que buscava uma mudança social e questionavam as consequências sociais do desenvolvimento tecnológico e científico, mas que, principalmente, criticavam os países latino americanos por adotar pensamentos baseados em países desenvolvidos, os quais não atendiam as demandas regionais. Fazia-se necessário, portanto, o desenvolvimento de um projeto para a política científica e tecnológica (PCT) com diretrizes claras e que atendesse as demandas dos países latino americanos (STRIEDER, 2012). Segundo Vaccarezza (2014), o PLACTS se torna importante no contexto brasileiro do movimento CTS pois tem características voltadas para a realidade dos países latino americanos que tem um histórico de atraso de desenvolvimento em relação à realidade norte americana e Europeia. No contexto brasileiro, Strieder (2012) destaca que é necessária uma maior sistematização da abordagem CTS no campo educacional e que não há instrumentos concretos para essas discussões nas escolas.

Segundo Santos e Mortimer (2002) o contexto atual se mostra favorável à exploração da abordagem CTS na educação, tanto no Ensino Médio como no Ensino Fundamental, contribuindo para a alfabetização e letramento científico e tecnológico. É necessário também se ter a consciência que não basta uma transposição acrítica dos currículos com enfoque CTS de outros países uma vez que a realidade brasileira é diferente, pois os países que iniciaram o movimento são geralmente países capitalistas centrais em que a Ciência e Tecnologia são bem mais desenvolvidos e não contam, por exemplo, com desigualdade social que está tão presente no contexto brasileiro (SANTOS; MORTIMER, 2002). O CTS no contexto brasileiro, portanto, significa discutir também cidadania, modelo de sociedade e tecnologia (SANTOS; MORTIMER, 2002). De forma geral, o movimento CTS atual pode ser entendido em três direções (GARCIA et al., 1996): 
■ No campo acadêmico: promovendo uma visão mais contextualizada da ciência e não essencialista.

$\square \quad$ No campo das políticas públicas: promovendo uma participação pública ativa em questões que envolvam ciência e tecnologia, tem o caráter mais prático e está voltado para as consequências sociais do desenvolvimento em CT.

$\square \quad$ No campo da educação: busca um ensino de ciências mais crítico e contextualizado, promovendo a participação social.

Todas essas três direções são importantes e constituem o movimento CTS. No entanto, no presente trabalho o foco será o movimento no campo educacional, abrangendo o ensino-aprendizagem e avaliação do aprendizado. Segundo Santos (1992), a prática docente em uma abordagem CTS, metodologicamente deve partir de um problema, em que o aluno mobilize o seu conhecimento sobre essa questão, chegando a tomada de decisão. A tomada de decisão se refere a resolução de problemas reais, que envolvam aspectos científicos, tecnológicos, sociais e políticos, levando a uma ativa participação na sociedade e formando um cidadão crítico e participativo (SANTOS, 1992). No entanto, o movimento CTS no Brasil no campo educacional ainda apresenta deficiências pois há escassez de materiais didáticos, a formação falha de professores e os vestibulares tradicionais serem voltados para conhecimentos enciclopédicos (ANDRELLA et al., 2011). Neste sentido, o novo ENEM como avaliação que permite a entrada no Ensino Superior com uma proposta voltada para abordagem CTS ajudaria na consolidação desse movimento no Brasil.

A abordagem CTS apresenta algumas características típicas, e entre elas podemos citar a interdisciplinaridade. Strieder (2012), ao analisar trabalhados publicados no seis primeiros Encontros Nacionais de Pesquisa em Educação em Ciências (ENPEC), aponta que a interdisciplinaridade é destacada em muitas pesquisas e revisões como necessária para discussões CTS, estabelecendo um diálogo com outras disciplinas, entre elas a filosofia e a história da Ciências. A abordagem contextualizada também é abordada nos estudos em CTS que indica que o conhecimento científico precisa estar articulado com aspectos sóciohistóricos, político, ambiental, tecnológico e ético (STRIEDER, 2012). A perspectiva CTS busca uma democratização dos processos decisórios, trabalhando a interdisciplinaridade e a resolução de situações problemas, visualizando o estudo da Ciências com um papel transformador (STRIEDER, 2012; SANTOS; MORTIMER, 2002).

Auler (2002), estabelece uma convergência entre a abordagem CTS e os pressupostos de Paulo Freire, pois para Freire a educação deve atuar como "um conhecimento crítico da realidade", favorecendo a dialogicidade e a problematização, e isto pode ser conseguido através de uma educação com perspectiva CTS. Nesse sentido, a abordagem CTS permite trabalhar a democratização dos processos de decisão e desmitificar mitos já muito enraizados na concepção popular como a neutralidade da Ciência e Tecnologia e o determinismo tecnológico (AULER, 2002). Assim, para Freire, a educação deve ser problematizadora e considerando a realidade do educando.

E não se diga que, se sou professor de biologia, não posso me alongar em considerações outras, que devo apenas ensinar biologia, como se o fenômeno vital pudesse ser compreendido fora da trama histórico-social, cultural e política. Como se a vida, a pura vida, pudesse ser vivida de maneira igual em todas as suas 
dimensões favela, no cortiço ou numa zona feliz dos 'Jardins' de São Paulo. Se sou professor de biologia, obviamente, devo ensinar biologia, mas, ao fazê-lo, não posso secioná-lo daquela trama. (FREIRE, 1992, pp.78-79).

\section{QUESTÕES COM ENFOQUE CTS NO ENEM}

Nos documentos oficiais brasileiros, tal como nos Parâmetros Curriculares Nacionais para o Ensino Médio (PCNEM), observa-se a expressão do enfoque CTS, uma vez que entre outras coisas, é mencionado o desejo que o aluno concluinte da Educação Básica desenvolva habilidades voltadas para contextualização sociocultural. Em consonância com os PCNEM o ENEM também tem em sua concepção teórica o diálogo entre Ciências, Tecnologia e Sociedade. Desde modo, na Matriz de Referência (MR) do ENEM para Ciências da Natureza e suas Tecnologias estão presentes 30 habilidades ${ }^{1}$ e 8 competências ${ }^{2}$ com objetivos que dialogam com a abordagem CTS. As 8 competências para Ciências da natureza e suas Tecnologias foram transcritas na integra a seguir:

Competência de área 1 - Compreender as ciências naturais e as tecnologias a elas associadas como construções humanas, percebendo seus papéis nos processos de produção e no desenvolvimento econômico e social da humanidade.

Competência de área 2 - Identificar a presença e aplicar as tecnologias associadas às ciências naturais em diferentes contextos.

Competência de área 3 - Associar intervenções que resultam em degradação ou conservação ambiental a processos produtivos e sociais e a instrumentos ou ações científico-tecnológicos.

Competência de área 4 - Compreender interações entre organismos e ambiente, em particular aquelas relacionadas à saúde humana, relacionando conhecimentos científicos, aspectos culturais e características individuais.

Competência de área $\mathbf{5}$ - Entender métodos e procedimentos próprios das ciências naturais e aplicá-los em diferentes contextos.

Competência de área 6 - Apropriar-se de conhecimentos da física para, em situações problema, interpretar, avaliar ou planejar intervenções científicotecnológicas.

Competência de área 7 - Apropriar-se de conhecimentos da química para, em situações problema, interpretar, avaliar ou planejar intervenções científicotecnológicas.

Competência de área 8 - Apropriar-se de conhecimentos da biologia para, em situações problema, interpretar, avaliar ou planejar intervenções científicotecnológicas.

Na competência 1, se expressa objetivos que visam a percepção da ciência e da tecnologia como construções humanas, portanto, rompendo com a visão da ciência como uma atividade neutra e distante da sociedade. Na competência 2, se expressa a necessidade de relacionar a ciências e as tecnologias a diferentes contextos, de modo, que seja possível a percepção de como a ciência e tecnologias se fazem presente no dia-a-dia e na vida prática. Neste aspecto, uma visão contextualizada e abrangente da ciência é positiva e se opõe a uma visão pontual, descontextualizada e fragmentada da realidade, onde os instrumentos científicos- 
tecnológicos são vistos distantes da sociedade. Na competência 3 é expresso o objetivo que o candidato compreenda as intervenções ambientais relacionando-as a processos sociais e produtivos bem como a produtos científicos tecnológicos, o que contribui para uma visão da ciências e tecnologia atrelados a sociedade. $\mathrm{Na}$ competência 4, se expressa o objetivo de "compreender interações entre organismos e ambiente, em particular aquelas relacionadas à saúde humana, relacionando conhecimentos científicos, aspectos culturais e características individuais.". Portanto, o ser humano é considerado como componente integrante da natureza e a saúde é tratada de modo a dialogar com aspectos culturais, que podem ser, por exemplo, hábitos de alimentação e higiene. Na competência 5 , se expressa o objetivo do entendimento de metodologias próprias da ciência e sua aplicação em diferentes contextos. Entre as habilidades dessa categoria o candidato é convidado a diagnosticar ou solucionar problemas de ordem social, econômica ou ambiental, valorizando, portanto, a visão crítica e a tomada de decisão frente a problemas. Por fim, nas competências 6,7 e 8 é explorado a capacidade de analisar, avaliar e planejar intervenções científicos nas áreas da Física, Química e Biologia, o que mais uma vez mostra a percepção do candidato como um sujeito ativo atuante na realidade e capaz de tomada de decisões. Além disso, é necessário que o candidato interprete conhecimentos técnicos da ciência e demonstre compreensão das metodologias cientificas. Analisando as competências e cada uma das suas habilidades podemos perceber que as habilidades também estão voltadas para uma abordagem CTS.

Assim, na MR do ENEM nota-se, também, que há a valorização da interdisciplinaridade e contextualização (BRASIL, 2009; SOBRINHO; SANTOS, 2014). Sobrinho e Santos (2014) em seu trabalho mostram de que forma a interdisciplinaridade e contextualização se coordenam nas provas de Ciências da Natureza e suas Tecnologias (CNT) e de Ciências Humanas e suas Tecnologias (CHT) permitindo que o professor trabalhe com aspectos do enfoque CTS. Dessa forma, os autores mostram que a interdisciplinaridade e a contextualização são parâmetros uteis para se identificar questões com enfoque sociocientífico. Neste trabalho, os autores concluem que na maioria das questões há pouca integração entre interdisciplinaridade e contextualização, sendo independentes ou com apenas uma desses fatores aparecendo no enunciado, o que representa uma fuga dos propósitos do ENEM e do que recomenda a sua MR. Além disso, quando se analisa a contextualização em questões é necessário observar se essa contextualização apenas cria um cenário ilustrativo para se cobrar um conhecimento enciclopédico, sendo uma contextualização fraca, ou se de fato promove a relação entre Ciências, Tecnologia e Sociedade, se caracterizando como contextualização forte (ANDRELLA et al., 2011). Outros trabalhos mostram que o ENEM contempla aspectos sociocientíficos, mas que em algumas questões esse contexto é desnecessário para a sua resolução (SOBRINHO et al., 2013).

De acordo com os elaboradores dos textos teóricos e metodológicos do ENEM, a contextualização acontece como decorrência das ideias de competência, interdisciplinaridade e situações-problemas (FERNANDES; MARQUES, 2012). Nesse sentido, o foco na competência permite minimizar as diferenças educacionais relacionadas as regiões geográficas e socioeconômicas, pois ao inserir a contextualização na prova é possível cobrar as competências de modo que os conteúdos conceituais não sejam o foco principal (FERNANDES; MARQUES, 2012). Ao se colocar uma situação-problema há a exploração de uma situação prática que surge como uma forma de contextualização, e que busca superar os 
exercícios tradicionais (FERNANDES; MARQUES, 2012). A interdisciplinaridade, por sua vez, também é mencionada no ENEM sendo entendida como a articulação de diferentes conhecimentos para o entendimento de mundo, processos e fenômenos. Cabe ainda destacar que há várias formas possíveis de disciplinas distintas se articularem: multidisciplinar, interdisciplinar, transdisciplinar e pandisciplinar. $\mathrm{Na}$ interdisciplinaridade há a intercomunicação efetiva entre as disciplinas, levando ao enriquecimento das relações entre elas (MACHADO, 2005). Já na multidisciplinaridade as articulações entre as disciplinas são sutis, de forma que cada disciplina preserva seus objetivos e características (MACHADO, 2005).

Andrella et al. (2011) analisaram as questões de Ciências da Natureza do ENEM de 2009 e 2010 a fim de determinar de que modo são expressas a relação CTS nelas. Com base na literatura, eles criaram cinco categorias provisórias que expressem concepções da perspectiva CTS nas questões CNT que julgamos relevantes também para o presente trabalho. São as seguintes: (1) visão da ciência; (2) aspectos vinculados a tecnologia; (3) relação entre Ciência e Tecnologia (C\&T) com a Sociedade; (4) forma de contextualização; (5) exigência de posicionamento frente a problemas sociais. Esses autores concluem que o ENEM de fato tem compromisso com a perspectiva CTS, quando exige um posicionamento crítico do aluno diante de problemas sociais. Embora, aspectos CTS estejam presentes em todas as habilidades expressas na MR, apenas algumas questões exploram esses aspectos. Andrella et al. (2011) apontam ainda que nenhuma questão analisada aborda o aspecto humano das ciências, passando a ideia da ciência como atividade neutra, e a tecnologia é abordada apenas em relação aos aspectos técnicos, sem mencionar os aspectos culturais. Essas características, portanto, contradizem as orientações da própria MR do ENEM (ANDRELLA et al., 2011).

Outros trabalhos, como o de Miranda et al. (2010), também se propõem a elucidar de que forma se dá as relações entre CTS, interdisciplinaridade e contextualização nas provas do ENEM. Nessa perspectiva, esses autores analisaram as questões que envolvem um conteúdo biológico na prova do ENEM de 2009, que é um ano marcado pela mudança estrutural e de objetivos desse exame. A conclusão desses autores foi que a contextualização é explorada de diversas maneiras e é vista como sendo algo presente no cotidiano do aluno, com a utilização de textos de revistas e sites. No entanto, em pouquíssimas questões a contextualização é realizada no sentido de exigir uma tomada de decisão em busca da transformação da realidade, pois na maioria das vezes ela é utilizada como ilustração dos conhecimentos científicos (MIRANDA et al., 2010). Os aspectos CTS não foram abordados profundamente uma vez que a exigência de posicionamento frente a problemas sociais foi pouco explorada e a formação de valores frente a problemas éticos (MIRANDA et al., 2010). Em relação a interdisciplinaridade, ela esteve ausente em $55 \%$ das questões analisadas por esses autores.

\section{METODOLOGIA}

O presente trabalho tem cunho essencialmente qualitativo e em um primeiro momento foi realizado uma leitura flutuante do caderno de Ciências da Natureza e suas Tecnologias (CNT) das provas do ENEM das edições de 2009 a 2014, totalizando 6 provas, com o intuito de se identificar as questões referentes a Biologia. A leitura flutuante se caracteriza como o primeiro contato com o documento da coleta de dados, sendo o momento em que se gera as impressões 
iniciais do texto a ser analisado (BARDIN, 2010). Os cadernos de Ciências da Natureza e suas Tecnologias tem 45 questões que englobam o conteúdo de

Biologia, Química e Física e, assim, poderia se esperar que em cada caderno tenha 15 questões com o conteúdo explicito da Biologia. No entanto, pela constituição da prova em que não há separação clara de conteúdo e pela sua tendência interdisciplinar, o número de questões em que o conteúdo de Biologia é um requisito necessário para a resolução das questões varia de forma que mais do que 15 questões possam ser consideradas como especificas da Biologia, relacionada a ela ou sendo necessário um conhecimento biológico para a sua resolução.

Desta forma, a análise de dados foi de acordo com a metodologia de Bardin (2010) realizada em três etapas: (1) pré-análise, (2) exploração do material e (3) tratamento dos resultados, inferências e interpretação. A escolha de utilizar Bardin se deve ao fato do conjunto metodológico proposto por essa autora nos fornece estrutura adequada para o desenvolvimento do presente trabalho e para análise de conteúdo das provas do ENEM. Além disso, Bardin é considerada uma autora de referência em metodologia de análise de conteúdo na área da educação.

Na pré-análise aconteceu a organização do material e por meio da leitura flutuante houve o primeiro contato com o caderno de provas de CNT do ENEM e uma visão geral desse exame. A partir disso, as questões em que o conteúdo de Biologia está presente foram selecionadas e foram determinados parâmetros que nos permitiram classificar as questões como tendo um enfoque sociocientífico.

A exploração do material constitui a segunda etapa na qual foi realizada uma leitura mais criteriosa e cuidadosa, na qual identificamos o potencial enfoque CTS das questões e, portanto, foram necessárias à definição de categorias e a realização de registros. Essa fase identificada por Bardin (2010) se caracteriza pela codificação, classificação e categorização. A categorização pode ser definida a priori com base no referencial teórico ou a posteriori, surgindo a partir da própria análise do material.

No presente trabalho a categorização foi definida a priori, com base na literatura, principalmente nas categorias apresentadas no trabalho de Andrella et al. (2011), sendo algumas delas adaptadas. Como forma de complementação, utilizamos também o trabalho de Miranda et al. (2010). Assim, elaborou-se o Quadro I no qual as categorias aparecem brevemente descritas, sendo que foi necessário a criação de subcategorias.

As categorias foram analisadas considerando o texto-base, o enunciado e o gabarito e desconsideramos os distratores, por não estarem relacionadas adequadamente a situação-problema proposta pelo item e por não corresponderem as habilidades e competências que se pretende com o item. Para a análise de algumas categorias não consideramos o texto-base, pois em algumas situações ele não é necessário, utilizado ou mobilizado para a resolução da questão ou não reflete bem a habilidade cobrada. 
Quadro I - Categorias, subcategorias e descrições

\begin{tabular}{|c|c|}
\hline Categorias & Descrições e subcategorias \\
\hline 1. Visão da Ciências & $\begin{array}{l}\text { Visões a respeito da Ciências que aparecem nas questões: } \\
\text { Ciência como uma forma de conhecimento neutro e } \\
\text { desvinculado da sociedade. } \\
\text { Ciência como uma construção humana e vinculado à } \\
\text { sociedade. } \\
\text { (ANDRELLA et al., 2011) }\end{array}$ \\
\hline $\begin{array}{l}\text { 2. Aspectos vinculados a } \\
\text { tecnologia }\end{array}$ & $\begin{array}{l}\text { Aspectos vinculados a tecnologia que aparecem na } \\
\text { questão: } \\
\text { 2.1. Aspectos técnicos: conhecimentos, habilidades e } \\
\text { técnicas; instrumentos, ferramentas e máquinas; recursos } \\
\text { humanos e materiais; matérias primas, produtos obtidos, } \\
\text { dejetos e resíduos. } \\
\text { 2.2. Aspecto organizacional: atividades econômica, } \\
\text { industrial e profissional; usuários, consumidores e } \\
\text { sindicatos. } \\
\text { 2.3. Aspecto cultural: valores e códigos de ética, crenças } \\
\text { sobre o progresso. } \\
\text { (ANDRELLA et al., 2011) }\end{array}$ \\
\hline $\begin{array}{l}\text { 3. Relação entre a } \\
\text { Ciência e Tecnologia (C \& } \\
\text { T) com a Sociedade }\end{array}$ & $\begin{array}{l}\text { De que forma as questões estabelecem relação entre C \& } \\
\text { T e sociedade: } \\
\text { 3.1. Conhecimentos científicos e tecnológicos são } \\
\text { apresentados desvinculados da sociedade. } \\
\text { 3.2. Conhecimentos científicos e tecnológicos são } \\
\text { apresentados como sofrendo uma influência da sociedade } \\
\text { ou influenciando nela e interferindo nas decisões sociais. } \\
\text { 3.3. Existência de uma articulação entre conhecimento } \\
\text { científico e tecnológico como fruto de interesses sociais e } \\
\text { influenciadores do plano social. } \\
\text { (Adaptado de ANDRELLA et al., 2011) }\end{array}$ \\
\hline 4. Contextualização & $\begin{array}{l}\text { 4.1. Não contextualizada } \\
\text { 4.2. Contextualização como ilustração para a questão ou } \\
\text { como necessária para a tomada de decisão frente, } \\
\text { podendo ocorrer por meio de textos, imagens e gráficos } \\
\text { ou da exploração do cotidiano do aluno. } \\
\text { (Adaptado de ANDRELLA et al., 2011; MIRANDA et al., } \\
\text { 2010) }\end{array}$ \\
\hline $\begin{array}{l}\text { 5. Exigência de } \\
\text { posicionamento frente a } \\
\text { problemas sociais }\end{array}$ & $\begin{array}{l}\text { 5.1. Sem exigência de posicionamento frente a problemas } \\
\text { sociais. } \\
\text { 5.2. Posicionamento crítico frente a problemas sociais e } \\
\text { diferentes interesses entre grupos sociais. } \\
\qquad \text { (Adaptado de ANDRELLA et al., 2011;) }\end{array}$ \\
\hline $\begin{array}{l}\text { 6. Articulação entre as } \\
\text { disciplinas }\end{array}$ & $\begin{array}{l}\text { Tipo de relação da Biologia com outras disciplinas. } \\
\text { 6.1. Sem relação expressiva } \\
\text { 6.2. Multidisciplinaridade } \\
\text { 6.3. Interdisciplinaridade }\end{array}$ \\
\hline
\end{tabular}

(Adaptado de MIRANDA et al., 2010)

(Fonte: Miranda et al., 2010; Andrella et al., 2011)

Na categoria 1, proposta por Andrella et al. (2011) procurou-se identificar a 
humano, e, portanto, vinculada à sociedade e a um contexto específico. É desejável que poucas questões possam ser enquadradas na subcategoria 1.1 que caracteriza a ciência neutra, pois ela vai de encontro com o mito da neutralidade científica, conforme mencionado por Japiassu (apud Santos; Mortimer, 2002; Strieder, 2012), em que a ciência é vista com infalível e que levará ao progresso e ao bem-estar social. No entanto, com o movimento CTS houve o repúdio e a negação dessa visão da Ciência como atividade pura e neutra, sendo que essa visão nos dias atuais é tida como inadequada e ultrapassada (GARCIA et al., 1996; STRIEDER, 2012). O olhar para Ciência como atividade neutra traz consigo um grande problema, pois a crença na neutralidade científica retira a responsabilidade de se refletir sobre as implicações e as consequências sociais e culturais da ciência (STRIEDER, 2012). Além disso, os currículos com ênfase em uma abordagem CTS devem preconizar a visão da ciência como atividade humana que está relacionada as tecnologias e aos aspectos sociais (SANTOS; MORTIMER, 2002).

Na categoria 2, também utilizamos na integra a classificação proposta por Andrella et al. (2011), considerando três aspectos referentes a tecnologia. Assim, a subcategoria 2.1 abrange os aspectos técnicos relacionados as tecnologias e espera-se que essa seja uma categoria de grande ocorrência nas questões pois se trata de uma visão mais tradicional referente ao ensino de ciências, onde é valorizado apenas o conhecimento objetivo e técnico. Já a subcategoria 2.2 abrange os aspectos organizacionais da tecnologia como a atividade econômica, industrial e profissional; usuários e consumidores das tecnologias e os sindicatos. Por fim, a subcategoria 2.3 aborda a tecnologia segundo os aspectos culturais, incluindo objetivos, valores e códigos de ética. Acredita-se que os aspectos organizacionais e culturais apareçam pouco nas questões do ENEM, uma vez que é recorrente a visão da tecnologia desvinculada da sociedade e do contexto cultural, valorizando-se mais os aspectos técnicos referentes ao desenvolvimento e uso dessas tecnologias (SANTOS; MORTIMER, 2002). No entanto, um currículo voltado para abordagem CTS deve promover a integração entre os aspectos científicos, tecnológicos e sociais, permitindo uma discussão sobre os aspectos sociais, políticos, históricos, culturais, éticos e morais (SANTOS; MORTIMER, 2002).

Na categoria 3, procurou-se mostrar de que maneira se dá a relação entre C\&T e sociedade nas questões do ENEM sendo necessária uma adaptação nas subcategorias propostas originalmente por Andrella et al. (2011). Na subcategoria 3.1 procurou-se identificar se os conhecimentos científicos e tecnológicos são apresentados de forma desvinculada da sociedade, o que é um indicativo de que a questão não é formulada com uma abordagem CTS. Na subcategoria 3.2 adaptamos e mesclamos duas categorias propostas separadamente por Andrella et al. (2011): (I) os conhecimentos científicos e tecnológicos são apresentados como sofrendo uma influência da sociedade e (II) os conhecimentos científicos e tecnológicos interferem nas decisões sociais, mas não são influenciados pela sociedade. Dessa forma, chegamos a categoria 3.2 do presente trabalho que é descrita como "conhecimentos científicos e tecnológicos são apresentados como sofrendo uma influência da sociedade ou influenciando nela e interferindo nas decisões sociais. Assim, adaptamos o item II pois o trabalho original propõe uma categoria em que a sociedade não interfere nos conhecimentos científico e tecnológico, o que não vai plenamente ao encontro de nossas conviç̧ões. Acreditamos que há uma intima relação entre C\&T e sociedade havendo uma associação de mão dupla, pois uma vez que o conhecimento científico e tecnológico pode interferir na sociedade, a sociedade, por sua vez, pode 
influenciar também nesse conhecimento. Deste modo, é inviável afirmar que os conhecimentos científicos e tecnológicos não são influenciados pela sociedade. A presente categoria, portanto, contempla essa associação em mão dupla entre C\&T. A primeira parte dessa categoria considera que os conhecimentos científicos e tecnológicos sofrem uma influência da sociedade, concebendo, portanto, a sociedade com um papel ativo uma vez que ela é capaz de influenciar nos rumos do conhecimento científico e tecnológico. Já na subcategoria 3.3 são classificadas questões que expressam uma articulação entre conhecimento cientifico e tecnológico como resultado de interesse sociais e influenciadores no plano social. Acredita-se que essa categoria terá pequena ocorrência nas questões do ENEM, pois há a necessidade de maior senso crítico para se perceber as relações entre os interesses sociais e a Ciências e Tecnologia, além de ser possível se analisar esse tipo de questão do ponto de vista pessoal, perdendo a objetividade inerente as questões de múltipla escolha as quais admitem apenas uma única resposta como a correta.

Sobrinho e Santos (2014), ao analisarem a prova de Ciências da Natureza e suas Tecnologia (CNT) e Ciências Humanas e suas Tecnologias (CHT) do ENEM aplicado em 2013 apontam que a interdisciplinaridade e a contextualização também podem ser utilizadas como parâmetros para identificação de questões com enfoque CTS, sendo essas duas características apoiadas também pela Matriz de Referência do ENEM. Esses autores apontam que há distintas formas de articulação e coordenação entre interdisciplinaridade e contextualização nas questões do ENEM, mas que ainda há dificuldades em se implementar questões que se aproximem do ideal de coordenação interdisciplinaridade/contextualização (SOBRINHO; SANTOS, 2014). A contextualização e interdisciplinaridade nas provas do ENEM também aparecem em outros trabalhos, como o de Miranda et al. (2010). Ainda para Miranda et al. (2010), a contextualização pode ocorrer por uma abordagem CTS quando contextos tecnológicos e/ou sociais são utilizados para dar significados a conceitos científico e a propiciar a ampla interpretação das ciências, o que permite a internalização dos conceitos científicos e a formação da cidadania (MIRANDA et al., 2010). Embora, Andrella et al. (2011) desconsiderem a interdisciplinaridade como parâmetro para a classificações das questões do ENEM, tanto ela quanto a contextualização serão categorias utilizadas nesta segunda fase do trabalho.

$\mathrm{Na}$ categoria 4 do presente trabalho consideramos que um item pode ser considerado contextualizado quando utiliza artifícios apenas para ilustrar conhecimentos científicos ou como sendo necessários para a resolução da questão e tomada de decisão frente a problemas (ANDRELLA et al., 2011; MIRANDA et al., 2010). Essa contextualização pode ser explorada e ocorrer de diversas maneiras, por meio de textos retirados de revistas cientificas, de sites governamentais, reportagens e livros (MIRANDA et al., 2010). Ela também acontece comumente por meio da exploração do cotidiano do candidato (RICARDO, 2005). Essa categoria tem um papel fundamental na categorização e análise das questões do ENEM, pois numa abordagem CTS espera-se que essa dimensão seja intensamente explorada.

$\mathrm{Na}$ categoria 5, por sua vez, procurou-se analisar se a questão exigia um posicionamento crítico frente a problemas sociais e a percepção de diferentes interesses de grupos sociais (ANDRELLA et al., 2011). Espera-se que poucas questões possam ser classificadas nessa categoria uma vez que nela, além de se explorar o senso crítico do candidato, é necessário considerar as opiniões pessoais, 
o que é difícil de se avaliar em uma prova de múltipla escolha aplicada em larga escala. As questões de múltipla escolha, embora práticas para avaliações em massa, apresentam limitações na exploração de habilidades, sobretudo naquelas que se diz respeito a comunicações de conhecimentos e opiniões como pondera Maia e Justi (2008). Portanto, esse tipo de categoria poderia se fazer mais presente em questões discursivas, em que é possível o candidato escrever seu posicionamento.

Na categoria 6 buscamos identificar de que formas as questões se articulam com outros campos do conhecimento. As articulações entre as disciplinas são importantes e positivas, pois caminham em busca de uma unidade perdida e da visão global em torno de assuntos, rompendo-se com a fragmentação dos conhecimentos que é algo muito comum no sistema de ensino atual (MACHADO, 2005). No mundo atual, se torna cada vez mais difícil delimitar um conhecimento como pertencente a um único campo do saber pois o avanço nas mais diversas áreas nos mostram as conexões existentes entre elas, o que torna necessário um olhar sistêmico para os conhecimentos (MACHADO, 2005).

Segundo o glossário de terminologias da Organizações das Nações Unidas para a educação, a ciência e a cultura (2016, p. 10) a abordagem multidisciplinar pode ser definida da seguinte forma:

Abordagem à integração curricular que enfoca primariamente as diferentes disciplinas e as diversas perspectivas que trazem para ilustrar um tópico, um tema ou uma questão. Um currículo multidisciplinar é aquele em que o mesmo tópico é estudado do ponto de vista de mais de uma disciplina.

Em contrapartida, segundo o mesmo glossário a interdisciplinaridade pode ser compreendida como (2016, p. 10):

Abordagem da integração curricular que gera compreensão de temas e ideias que perpassam as disciplinas e das conexões entre diferentes disciplinas e sua relação com o mundo real. Normalmente, enfatiza processo e significado - e não produto e conteúdo - ao combinar conteúdos, teorias, metodologias e perspectivas de duas ou mais disciplinas.

Desta maneira percebe-se que na multidisciplinaridade as disciplinas podem ser consideradas individualmente, enquanto na interdisciplinaridade as disciplinas estão mais intimamente relacionadas e podem ser exploradas de forma mais abrangente.

Desta forma, as questões foram consideradas como pertencentes a subcategoria 6.1 quando apenas o conteúdo estritamente biológico era necessário para a resolução da questão. Já a multidisciplinaridade (subcategoria 6.2) foi considerada quando há um pequeno e sutil diálogo entre as disciplinas, de forma que cada uma delas preservem seus objetivos e características próprias (MACHADO, 2005). Já a interdisciplinaridade (subcategoria 6.3), muito mencionada nas discussões educacionais, foi considerada quando há a comunicação efetiva entre as disciplinas, de forma que ocorra um enriquecimento da questão (MACHADO, 2005).

Por fim, no tratamento dos resultados fizemos inferências, interpretamos as questões e as analisamos. Após a identificação das questões com enfoque sociocientífico, foi calculado o percentual de expressão de cada categoria dentro 
do universo das questões especificas da Biologia das provas de 2009 a 2014 do ENEM e os dados referentes as categorias foram organizadas em gráficos.

\section{RESULTADOS E DISCUSSÃO}

Ao todo foram analisadas 112 questões distribuídas nas provas do ENEM de 2009 a 2014, que foram classificadas nas categorias e subcategorias anteriormente descritas. A seguir estão os resultados quantitativos, convertidos em porcentagem e organizados em gráficos. São apresentados também algumas questões que representam as subcategorias adotadas.

Assim, para a categoria 1 em que se identificou se as questões expressavam uma visão neutra da Ciência ou a Ciência como construção humana, se obteve os seguintes resultados para um universo de 112 questões.

Gráfico 1 - Resultado quantitativo geral para a categoria 1.

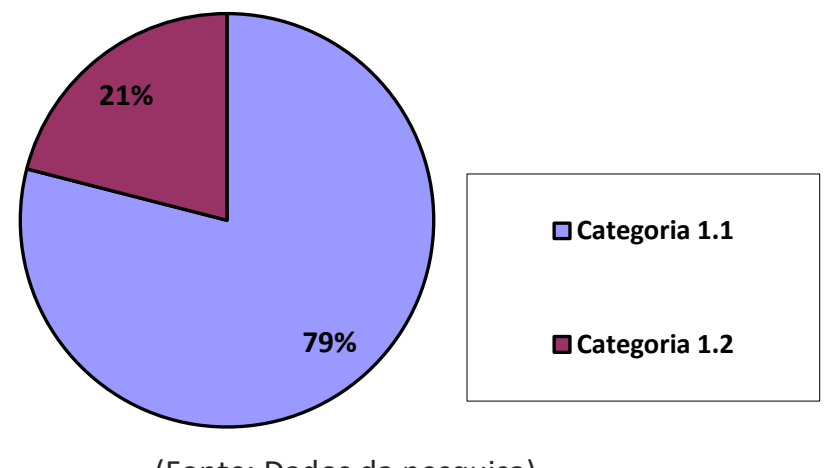

(Fonte: Dados da pesquisa)

Pelo gráfico anterior percebe-se que a maioria dos itens demonstram uma visão da ciência como neutra, o que corresponde a 88 questões ou $78,5 \%$ das questões analisadas. Esses resultados vão de encontro ao observado também por Andrella et al. (2011) que indicam que as questões do ENEM de 2009 e 2010 expressam uma visão da ciência neutra, desvinculada dos valores humanos e sem estabelecer relações entre a produção de conhecimento e suas finalidades. No entanto, a competência 1 da MR do ENEM destaca que o candidato deve "compreender as ciências naturais e as tecnologias a elas associadas como construções humanas" e assim as questões que expressão uma visão neutra da ciência e não problematizada vão contra ao que é recomendado nos próprios documentos oficiais do ENEM e são incompatíveis com uma abordagem CTS (ANDRELLA et al., 2011).

Deste modo, para a categoria 1 (visão da Ciências) a questão a seguir representa o que se considerou como uma concepção da ciência como atividade neutra (subcategoria 1.1): 
Figura 2 - Questão que representa a subcategoria "1.1. Concepção de Ciências como atividade neutra".

\begin{abstract}
QUESTÃO 62
Nos dias de hoje podemos dizer que praticamente todos os seres humanos já ouviram em algum moment falar sobre o DNA e seu papel na hereditariedade da maioria dos organismos. Porém, foi apenas em 1952, un ano antes da descrição do modelo do DNA em dupla hélice por Watson e Crick, que foi confirmado sem sombr: de dúvidas que o DNA é material genético. No artigo em que Watson e Crick descreveram a molécula de DNA eles sugeriram um modelo de como essa molécula deveria se replicar. Em 1958, Meselson e Stahl realizaran experimentos utilizando isótopos pesados de nitrogênio que foram incorporados às bases nitrogenadas para avalia como se daria a replicação da molécula. A partir dos resultados, confirmaram o modelo sugerido por Watson e Crick que tinha como premissa básica o rompimento das pontes de hidrogênio entre as bases nitrogenadas. GRIFFTHS, A. J. F. et al. Introduçăo à Genética. Rio de Janeiro: Guanabara Koogan, 200:

Considerando a estrutura da molécula de DNA e a posição das pontes de hidrogênio na mesma, os experimento realizados por Meselson e Stahl a respeito da replicação dessa molécula levaram à conclusão de que

A a replicação do DNAé conservativa, isto é, a fita dupla filha é recém-sintetizada e o filamento parental é conservado

B a replicação de DNA é dispersiva, isto é, as fitas filhas contêm DNA recém-sintetizado e parentais em cada uma

das fitas.

(C) a replicação é semiconsenvativa, isto é, as fitas filhas consistem de uma fita parental e uma recém-sintetizada.

O replicação do DNA é conservativa, isto é, as fitas filhas consistem de moléculas de DNA parental.

$\boldsymbol{\Theta}$ a replicação é semiconservativa, isto é, as fitas filhas consistem de uma fita molde e uma fita codificadora.
\end{abstract}

(Fonte: ENEM 2011 - caderno amarelo)

Nesta questão pode-se observar que a ciência é vista de maneira neutra e desvinculada da sociedade. Em seu enunciado a questão descreve a descoberta do modelo do DNA e da forma de replicação dessa molécula, mas em nenhum momento as influências sociais dessa descoberta são consideradas ou se menciona qual o objetivo da pesquisa sobre isso. Além disso, as questões éticas e morais na ciência são negligenciadas, uma vez que se sabe que a suposta descoberta do DNA por dois grupos distintos de pesquisadores carrega consigo uma série de conflitos e que cria um cenário favorável para a discussão desse tema. No entanto, esse tipo de discussão é dificultado em itens de múltipla escolha, sendo mais propicio de ser feito, por exemplo, em sala de aula ou em questões abertas. O gabarito (letra C), por sua vez, cobra do candidato apenas o nome desse processo de replicação e em que ele consiste. Além de ser possível o candidato conseguir chegar a resposta correta sem ler o texto-base, o gabarito traz consigo uma proposta nos modelos tradicionais de avaliação, onde a memória e o conhecimento enciclopédico se fazem necessários para a resolução da questão.

De maneira contrária, na subcategoria 1.2 buscamos identificar questões em que a ciência seja considerada como uma construção humana, não neutra e que acontece em um determinado contexto histórico, social, econômico e político, de maneira semelhante a questão presente na Figura 3.

No texto-base da questão anterior, percebe-se que a ciência não é vista como neutra e que é considerado os contextos de produção do conhecimento e as influências das descobertas cientificas e tecnológicas para a sociedade. Deste modo é apresentado as relações que acontecem no campo das ciências, como a parceria da UnB com a iniciativa privada, e é explicitado de que maneira a produção de insulina por meio da técnica do DNA recombinante é mais vantajosa em relação a extração do hormônio do pâncreas de animais. A alternativa correta (letra D), por sua vez explicita a vantagem desse método para os indivíduos diabéticos de uma população pois a fabricação de insulina artificial pelo novo método permite que esse hormônio seja produzido três vezes mais rápido em comparação a técnica tradicional. Assim, a questão relaciona as descobertas cientificas-tecnológicas com o bem-estar e saúde da sociedade, de forma que essa questão possa ser considerada como tendo uma abordagem CTS. 
Figura 3 - Questão que representa a categoria "1.2. Concepção de Ciências como construção humana".

Um novo método para produzir insulina artificial que utiliza tecnologia de DNA recombinante foi desenvolvido por pesquisadores do Departamento de Biologia Celular da Universidade de Brasília (UnB) em parceria com a iniciativa privada. Os pesquisadores modificaram geneticamente a bactéria Escherichia coli para torná-la capaz de sintetizar o hormônio. O processo permitiu fabricar insulina em maior quantidade e em apenas 30 dias, um terço do tempo necessário para obtê-la pelo método tradicional, que consiste na extração do hormônio a partir do pâncreas de animais abatidos.

Ciencia Hoje, 24 abr. 2001. Disponivel em: http://cienciahoje vol.com.br (adaptado)

A produção de insulina pela técnica do DNA recombinante tem, como consequência,

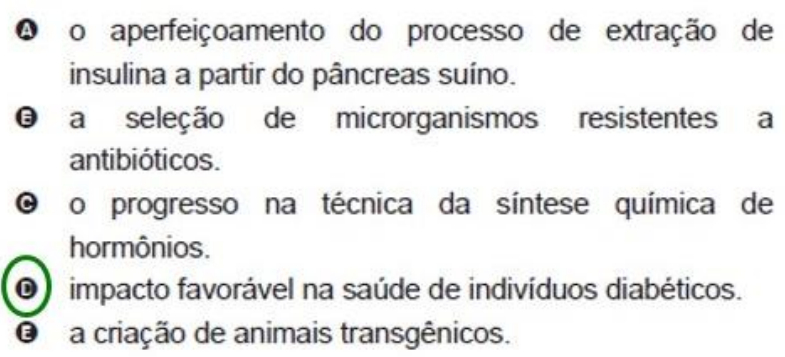

(Fonte: ENEM 2009 - Caderno azul)

Em relação a categoria 2 que retrata os aspectos vinculados a tecnologia, subdividimos em três subcategorias, que retratam os aspectos técnicos, organizacional e culturais. Assim, para a subcategoria 2.1, que busca identificar os aspectos técnicos abordados pela questão, temos como exemplo a questão 41 de 2009 (Figura 4).

Na questão 41 fica claro que os conhecimentos técnicos são privilegiados em relação as tecnologias atuais de análise de DNA. A questão cria um contexto para a exploração do tema, que no caso é um acidente de carro com uma vítima fatal carbonizada, em que o candidato precisa mobilizar os seus conhecimentos em relação as técnicas de análise de DNA, as características e padrões de herança dos cromossomos autossômicos, cromossomos sexuais e DNA mitocondrial. Assim, o gabarito (letra A) conclui que a melhor escolha é a análise, pela perícia, do DNA mitocondrial para a identificação da vítima pois ele é transmitido pela linhagem materna e há várias copias dele em cada célula. Como há uma maior quantidade de material disponível para análise, as chances de sucesso e identificação da vítima são maiores.

Em contrapartida não foram identificadas questões que pudessem ser classificadas nas categorias 2.2 e 2.3 , uma vez que não foi possível se perceber a valorização dos aspectos organizacionais e culturais vinculados as tecnologias. As questões não mencionam os interesses econômicos relaciona dos as tecnologias e nem a relação dos consumidores com ela, também são negligenciados os valores 
éticos e as possíveis crenças sobre o desenvolvimento tecnológico. Esses resultados vão de encontro ao pesquisado por Andrella et al. (2011) ao analisarem as provas do ENEM de 2009 e 2010, o que nos mostra que, desde então, o exame não teve evoluções em relação a esse quesito. No entanto, a competência 2 do ENEM preza para que o candidato saiba "reconhecer as tecnologias associadas às ciências naturais em diferentes contextos", mas novamente observamos que as questões não cumprem integralmente o recomendado uma vez que os aspectos técnicos da tecnologia são privilegiados em detrimento de outros.

Figura 4 - Questão que representa a subcategoria "2.1 Aspectos técnicos vinculados a tecnologia".

\section{Questad 41}

Uma vítima de acidente de carro foi encontrada carbonizada devido a uma explosão. Indícios, como certos adereços de metal usados pela vítima, sugerem que a mesma seja filha de um determinado casal. Uma equipe policial de perícia teve acesso ao material biológico carbonizado da vítima, reduzido, praticamente, a fragmentos de ossos. Sabe-se que è possivel obter DNA em condições para análise genética de parte do tecido interno de ossos. Os peritos necessitam escolher, entre cromossomos autossômicos, cromossomos sexuais ( $\mathrm{X}$ e Y) ou DNAmt (DNA mitocondrial), a melhor opção para identificação do parentesco da vitima com o referido casal. Sabe-se que, entre outros aspectos, o número de cópias de um mesmo cromossomo por célula maximiza a chance de se obter moléculas não degradadas pelo calor da explosão.

Com base nessas informações e tendo em vista os diferentes padrőes de herança de cada fonte de DNA citada, a melhor opção para a perícia seria a utilizaçăo

( ) do DNAmt, transmitido ao longo da linhagem materna, pois, em cada célula humana, há várias cópias dessa molécula.

e do cromossomo $X$, pois a vítima herdou duas cópias desse cromossomo, estando assim em número superior aos demais.

() do cromossomo autossômico, pois esse cromossomo apresenta maior quantidade de material genético quando comparado aos nucleares, como, por exemplo, o DNAmt

( - do cromossomo Y, pois, em condições normais, este é transmitido integralmente do pai para toda a prole $\mathrm{e}$ está presente em duas cópias em células de individuos do sexo feminino.

* de marcadores genéticos em cromossomos autossômicos, pois estes, além de serem transmitidos pelo pai e pela mãe, estão presentes em 44 cópias por célula, e os demais, em apenas uma.

(Fonte: ENEM 2009 - Caderno Azul)

Assim, para a categoria 2 em que se analisou as relações entre a C\&T e Sociedade expressa pela questão observou-se que apenas a subcategoria 2.1 - que se refere aos conhecimentos técnicos - foi contemplada pelo exame.

Na categoria 3 (relação entre a Ciência e Tecnologia (C \& T) com a Sociedade), por sua vez, buscamos analisar de que maneira as questões estabelecem as relações entre Ciência \& Tecnologia com a sociedade, sendo que essas relações poderiam ser enquadradas em três subcategorias. Na subcategoria 3.1 buscamos identificar questões em que os conhecimentos científicos e tecnológicos são 
apresentados de forma desvinculada da sociedade, e, portanto, não vão de encontro com uma abordagem CTS. A questão 60 (Figura 5) do ano de 2012 ilustra esse tipo de visão.

Na questão 60, os transgênicos são mostrados de forma desvinculada da sociedade, uma vez que não se menciona a influência dessa técnica num contexto social. É negligenciado, por exemplo, os aspectos ligados a ética, impactos ambientais, impactos a saúde dos consumidores e influência para a economia e indústria, temas esses que dialogam com os produtos transgênicos. 0 candidato deve demonstrar apenas conhecimentos em relação aos aspectos técnicos, identificando de que maneira o milho transgênico expressa uma característica de interesse para o agricultor, o que se dá pela tradução do RNA mensageiro transcrito do DNA recombinante, chegando ao gabarito E. Observa-se, portanto, que esse tipo de questão se aproxima mais das questões tradicionais.

Figura 5 - Questão que representa a subcategoria "3.1. Conhecimentos científicos e tecnológicos são apresentados desvinculados da sociedade".

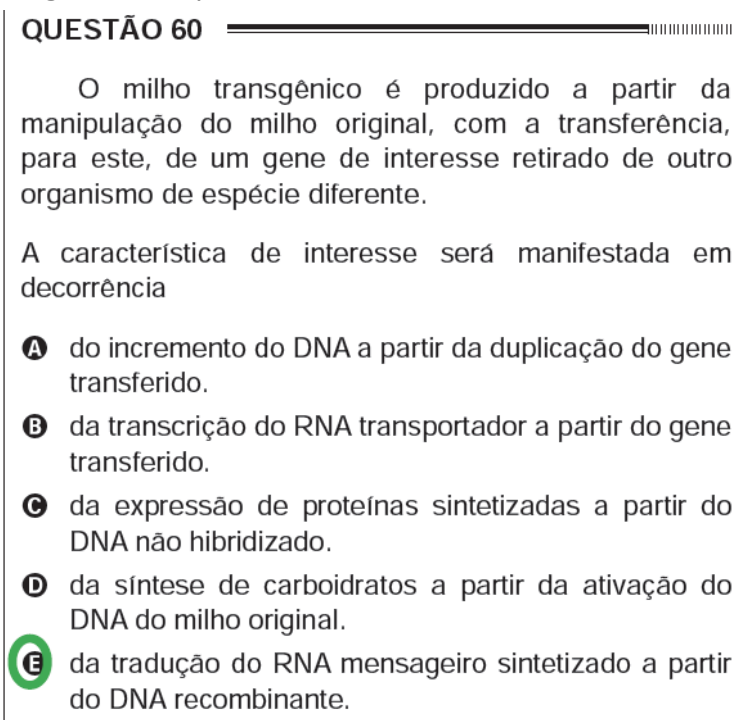

A do incremento do DNA a partir da duplicação do gene transferido.

B da transcrição do RNA transportador a partir do gene transferido.

C da expressão de proteínas sintetizadas a partir do DNA não hibridizado.

D da síntese de carboidratos a partir da ativação do DNA do milho original.

(E) da tradução do RNA mensageiro sintetizado a partir do DNA recombinante.

(Fonte: ENEM 2012 - Caderno Amarelo)

Na subcategoria 3.2 foram identificadas questões em que conhecimentos científicos e tecnológicos são apresentados como sofrendo uma influência da sociedade ou influenciando nela e interferindo em decisões sociais. A questão 62 do ano de 2013 apresentada a seguir se enquadra nessa categoria pois mostra os conhecimentos sofrendo uma influência da sociedade.

Na questão 62, podemos perceber que é apresentada uma visão em que as demandas da sociedade influenciam no conhecimento científico e tecnológico. Desta forma, o surto de varíola no final do século XVIII foi um fator que demonstrou a necessidade de se desenvolver tecnologias que permitissem a profilaxia dessa doença, o que culminou com a invenção da vacina por Edward Jenner. $O$ gabarito (letra A) ressalta a contribuição desse médico para a prevenção dessa doença e de diversas outras de origem infectocontagiosas. Essa categoria vai de acordo com uma abordagem CTS e valoriza o papel ativo da sociedade no desenvolvimento tecnológico e científico uma vez que ela demonstra quais são as suas demandas e necessidades. Assim, em suas pesquisas os cientistas precisam responder também ao contexto social. 
Figura 6 - Questão que representa a subcategoria " 3.2. Conhecimentos científicos e tecnológicos são apresentados como sofrendo uma influência da sociedade ou influenciando nela e interferindo em decisões sociais.".

\begin{abstract}
QUESTÃO 62
Milhares de pessoas estavam morrendo de varíola humana no final do século XVIII. Em 1796, o médico Edward Jenner (1749-1823) inoculou em um menino de 8 anos o pus extraído de feridas de vacas contaminadas com o vírus da varíola bovina, que causa uma doença branda em humanos. O garoto contraiu uma infecção benigna e, dez dias depois, estava recuperado. Meses depois, Jenner inoculou, no mesmo menino, o pus varioloso humano, que causava muitas mortes. O menino não adoeceu.
\end{abstract}

Disponivel em: www.bbc.co.uk. Acesso em: 5 dez. 2012 (adaptado).

Considerando o resultado do experimento, qual a contribuiçāo desse médico para a saúde humana?

(A) A prevenção de diversas doenças infectocontagiosas em todo o mundo.

B A compreensão de que vírus podem se multiplicar em matéria orgânica.

C O tratamento para muitas enfermidades que acometem milhōes de pessoas.

D O estabelecimento da ética na utilização de crianças em modelos experimentais.

( A explicação de que alguns vírus de animais podem ser transmitidos para os humanos.

(Fonte: ENEM 2013 - Caderno Amarelo)

Nessa subcategoria foram consideradas também as questões que expressam que os conhecimentos científicos e tecnológicos interferem nas decisões sociais e são influenciados pela sociedade. Essa subcategoria, portanto, se mostra muito voltada para abordagem CTS uma vez que se percebe a conexão de mão dupla entre a sociedade e $C \& T$.

Na subcategoria 3.3, por sua vez, buscamos classificar as questões que expressam a existência de uma articulação entre o conhecimento científico e tecnológico como fruto de interesses sociais e influenciadores do plano social. A questão 87 de 2010 (Figura 7) é um exemplo para esse tipo de questão.

Na questão 87, mostra de que maneira a rotação de cultura pode ser benéfica para os produtores de cana de modo que não apenas o conhecimento técnico é valorizado, mas também os aspectos relacionados ao contexto social e econômico. Assim, o candidato precisa relacionar a rotação de cultura a fixação de nitrogênio realizado pelas plantas leguminosas e o benefício econômico decorrente da venda de produtos como soja, amendoim e o feijão. Esse tipo de questão consegue, portanto, relacionar assertivamente os conhecimentos científicos (rotação de cultura e ciclo do nitrogênio) ao um contexto social e aos interesses de determinados grupos, na questão, notadamente os agricultores que tem no solo um recurso essencial para a produção, mas que também necessitam de retorno financeiro. O ENEM explorar os aspectos sociais ligados aos conhecimentos das 
ciências da natureza representa um avanço em relação aos tradicionais vestibulares que não abrangiam esses aspectos (ANDRELLA et al., 2011; PINHEIRO; OSTERMANN, 2010)

Figura 7 - Questão que representa a subcategoria "3.3. Existência de uma articulação entre conhecimento científico e tecnológico como fruto de interesses sociais e influenciadores do plano social."

\section{Questão 87}

De $15 \%$ a $20 \%$ da área de um canavial precisa ser renovada anualmente. Entre o período de corte e o de plantação de novas canas, os produtores estão optando por plantar leguminosas, pois elas fixam nitrogênio no solo, um adubo natural para a cana. Essa opção de rotação é agronomicamente favorável, de forma que municípios canavieiros são hoje grandes produtores de soja, amendoim e feijão.

As encruzinadas da fome. Planeta. S30 Paulo, ano 36, $n^{*} .430$, jul. 2008 (adaptado) A rotação de culturas citada no texto pode beneficiar economicamente os produtores de cana porque

Q a decomposição da cobertura morta dessas culturas resulta em economia na aquisição de adubos industrializados.

B o plantio de cana-de-açúcar propicia um solo mais adequado para o cultivo posterior da soja, do amendoim e do feijão.

$\odot$ as leguminosas absorvem do solo elementos químicos diferentes dos absorvidos pela cana, restabelecendo o equilíbrio do solo.

- a queima dos restos vegetais do cultivo da canade-açúcar transforma-se em cinzas, sendo reincorporadas ao solo, o que gera economia na aquisiçăo de adubo.

(9) a soja, o amendoim e o feijão, além de possibilitarem a incorporação ao solo de determinadas moléculas disponíveis na atmosfera, são grãos comercializados no mercado produtivo.

(Fonte: ENEM 2010 - Caderno Azul)

Deste modo, para a categoria 3 em que se identificou as relações entre C\&T e a sociedade, $56 \%$ das questões correspondiam a categoria $3.1,38 \%$ correspondia a categoria 3.2 e apenas $6 \%$ das questões correspondiam a categoria 3.3. Os resultados estão esquematizados no Gráfico 2. 
Gráfico 2 - Resultado quantitativo geral para a categoria 3.

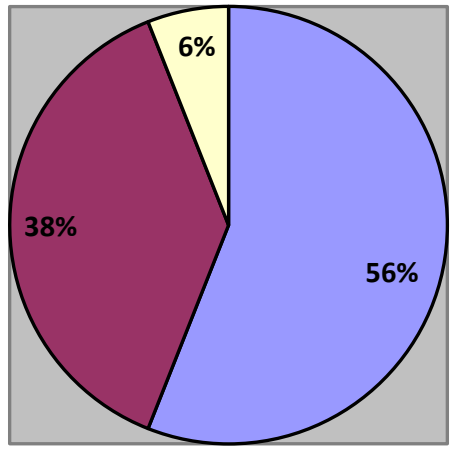

\section{口Categoria 3.1 \\ 口Categoria 3.2 \\ $\square$ Categoria 3.3.}

(Fonte: Dados da pesquisa)

Na categoria 4 (contextualização) buscamos contemplar as questões que utilizam a contextualização nos seus enunciados, seja ela apenas como a ilustração para um conhecimento ou como realmente necessária para a resolução da questão. Assim, de todas as questões analisadas, apenas três questões foram consideradas descontextualizada e se assemelham aos estilos de questão tradicional. A questão a seguir é um exemplo da categoria 4.1 não contextualizada.

Figura 8 - Questão que representa a subcategoria "4.1 Não contextualizada".

\section{Questao 21}

Os seres vivos apresentam diferentes ciclos de vida, caracterizados pelas fases nas quais gametas são produzidos e pelos processos reprodutivos que resultam na geração de novos individuos

Considerando-se um modelo simplificado padrão para geração de individuos viáveis, a altemativa que corresponde ao observado em seres humanos é:
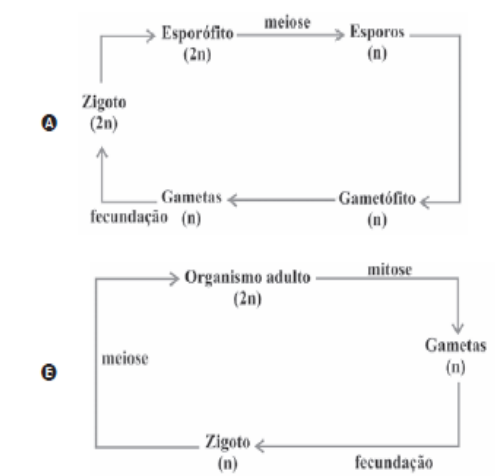
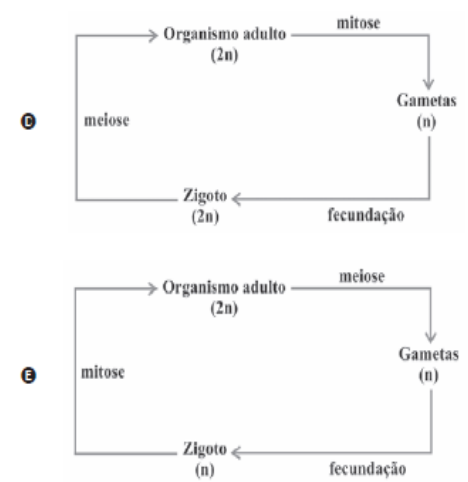

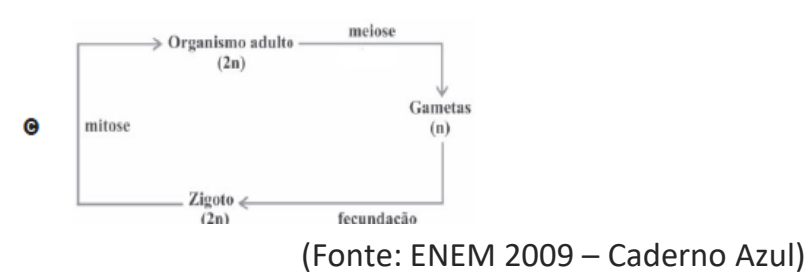

Por outro lado, todas as outras questões, correspondendo a $97 \%$ das questões analisadas, se mostraram contextualizada, sendo que isso ocorreu por meio de textos, ilustrações, descrição de experimentos, situações fictícias ou da própria 
utilização do cotidiano do candidato. A questão 33 do ENEM de 2009 é um exemplo de questão contextualizada em que a leitura e interpretação da imagem e do textobase, os quais descreve os resultados de uma pesquisa científica, se mostram essenciais para a resolução da questão.

Figura 09 - Questão A09AZ33 que representa a subcategoria "Contextualização como ilustração para a questão ou como necessária para a tomada de decisão frente".

\section{Questao 33}

Os ratos Peromyscus polionotus encontram-se distribuidos em ampla região na América do Norte. A pelagem de ratos dessa espécie varia do marrom claro até o escuro, sendo que os ratos de uma mesma população têm coloração muito semelhante. Em geral, a coloração da pelagem também é muito parecida à cor do solo da regiâo em que se encontram, que também apresenta a mesma variação de cor, distribuída ao longo de um gradiente sul-norte. Na figura, encontram-se representadas sete diferentes populaçôes de $P$. polionotus. Cada população é representada pela pelagem do rato, por uma amostra de solo e por sua posição geográfica no mapa.

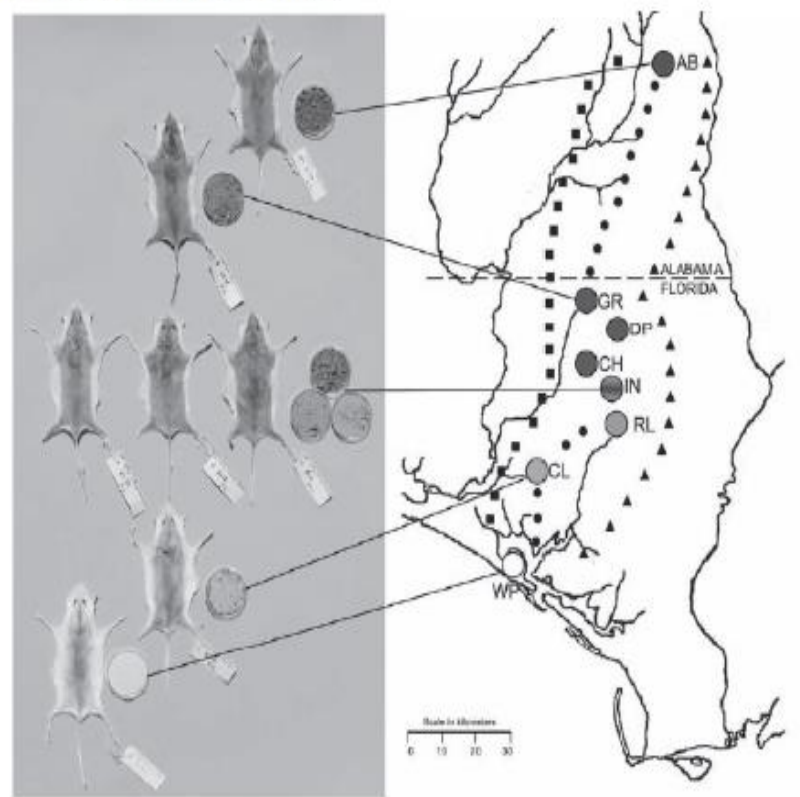

MULLEN, L M.; HOEKSTRA, H. E. Natura selecton along an enviromenta gadent a casssc alne in mouse plgnentabton. Evolution, 200 O mecanismo evolutivo envolvido na associação entre cores de pelagem e de substrato é

- a alimentação, pois pigmentos de terra são absorvidos e alteram a cor da pelagem dos roedores.

( ) o fluxo gênico entre as diferentes populações, que mantém constante a grande diversidade interpopulacional.

- a seleção natural, que, nesse caso, poderia ser entendida como a sobrevivência diferenciada de indivíduos com características distintas.

- a mutação genética, que, em certos ambientes, como os de solo mais escuro, têm maior ocorrência e capacidade de alterar significativamente a cor da pelagem dos animais.

- a herança de caracteres adquiridos, capacidade de organismos se adaptarem a diferentes ambientes e transmitirem suas características genéticas aos descendentes

(Fonte: ENEM 2010 - Caderno Azul)

Deste modo, para a categoria 4 em que se identificou as questões contextualizadas, obtemos os seguintes resultados. 
Gráfico 3 - Resultado quantitativo geral para a categoria 4 - contextualização.

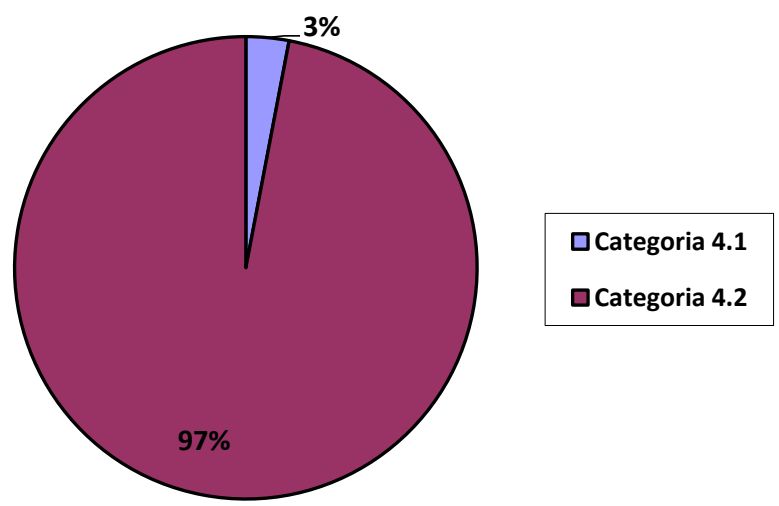

(Fonte: Dados da pesquisa)

Era esperado que a grande maioria das questões do ENEM fossem contextualizada uma vez que esse é um dos eixos estruturadores do exame (BRASIL, 2009). Para os elaboradores no novo ENEM, a contextualização ocorre em decorrência da interdisciplinaridade, situações-problemas e do conceito de competência (FERNANDES; MARQUES, 2012). Então, a contextualização pode ser entendida como uma forma de elaboração de questões em que o conteúdo conceitual propriamente dito fica como "pano de fundo" para permitir a ressignificação e compreensão por parte dos estudantes (FERNANDES; MARQUES, 2012). Nesse sentido, a interdisciplinaridade é entendida como um modo de se gerar um contexto adequado para as questões (FERNANDES; MARQUES, 2012). No entanto, isso não significa que os conteúdos conceituais não sejam importantes ou necessários para a resolução da prova (FERNANDES; MARQUES, 2012).

Os elaboradores do novo ENEM mencionam ainda que muitas vezes a contextualização é entendida como um pretexto ou uma ilustração para se cobrar aspectos puramente conceituais em que o contexto não tem importância ou relevância para a resolução da questão (FERNANDES; MARQUES, 2012). No entanto, esse tipo de contextualização, na opinião dos elaboradores do ENEM não é desejável e se constitui como um equívoco na elaboração de questões (FERNANDES; MARQUES, 2012). Nesse sentido, outros autores ao analisarem a prova do ENEM apontam que muitas vezes o contexto aparece apenas como ilustração, mas não é um requisito necessário para a resolução da questão pelo candidato (MIRANDA et al., 2010; SOBRINHO et al., 2013). Andrella et al. (2011), ao analisarem as provas de 2009 e 2010 do ENEM também mencionam que as questões podem apresentar uma contextualização fraca quando utilizam o contexto - por exemplo a menção ao dia-a-dia do candidato - apenas como artificio para se cobrar um conteúdo meramente conceitual, sem estabelecer relações sociais, culturais e políticas com o conteúdo. A questão a seguir, do ENEM de 2011, é um exemplo de questão em que contexto é ilustrativo e não essencial para a resolução da questão. Vejamos a seguir um exemplo de questão em que a contextualização é utilizada como ilustração. 
Figura 10 - Questão A11AM58 que exemplifica contextualização como ilustração para a questão.

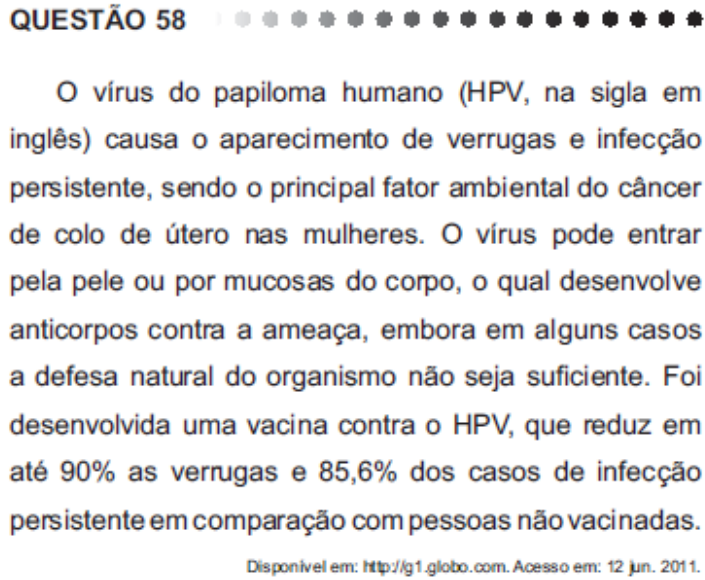

O benefício da utilização dessa vacina é que pessoas vacinadas, em comparação com as não vacinadas, apresentam diferentes respostas ao vírus HPV em decorrência da

A alta concentração de macrófagos.

B elevada taxa de anticorpos específicos anti-HPV circulantes.

C aumento na produção de hemácias após a infecção por vírus HPV.

D rapidez na produção de altas concentrações de linfócitos matadores.

(૯) presença de células de memória que atuam na resposta secundária.

(Fonte: ENEM 2010 - Caderno Amarelo)

Na questão anterior, o texto sobre a criação de vacina do HPV serve como ilustração para se cobrar conteúdo conceitual. Observa-se que caso o candidato ignore o texto de contextualização, leia apenas o comando da questão e domine o conteúdo cobrado, é possível se chegar a resposta correta, sem a leitura e/ou compreensão do texto de contextualização.

Andrella et al. (2011) indicam que a prova do ENEM pode ser considerada altamente contextualizada uma vez que a maioria das questões apresentam um contexto como ilustração para o item ou como necessário para a sua resolução. Pinheiro e Ostermann (2010) indicam que a principal diferença das provas tradicionais dos vestibulares e da prova do ENEM é em relação a contextualização. Esses autores observaram que na prova de 2009 do ENEM, quase 90\% das questões de física eram contextualizadas, diferentemente do que ocorria para as tradicionais avaliações dos vestibulares dessa disciplina (PINHEIRO; OSTERMANN, 2010)

Desta forma, o presente estudo e trabalhos anteriores apontam que o ENEM pretende utilizar questões que são realmente contextualizadas, isto é, que apresente em seu enunciado informações essenciais para a resolução da questão e que permitam a compreensão de mundo pelo candidato, de forma que seja 
possível estabelecer relações sociais com o conhecimento científico e tecnológico. No entanto, muitas questões apresentam contextualização meramente ilustrativas para um conteúdo e sem estabelecer as relações sociais.

$\mathrm{Na}$ categoria 5 buscamos identificar se a questão exige ou não um posicionamento frente a problemas sociais e diferentes interesses entre grupos sociais. A questão 13 é um exemplo da subcategoria 5.2 Exigência de posicionamento frente a problemas sociais.

Figura 11 - Questão A09AZ13 que representa a categoria "5.2 Exigência de posicionamento frente a problemas sociais".

\section{Questad 13}

A abertura e a pavimentação de rodovias en zonas rurais e regiōes afastadas dos centros urbanos. por um lado, possibilita melhor acesso e maior integração entre as comunidades, contribuindo com o desenvolvimento social e urbano de populações isoladas. Por outro lado, a construção de rodovias pode trazer impactos indesejáveis ao meio ambiente, visto que a abertura de estradas pode resultar na fragmentação de habitats, comprometendo o fluxo gènico e as interaçōes entre espécies silvestres, além de prejudicar o fluxo natural de rios e riachos, possibilitar 0 ingresso de espécies exóticas em ambientes naturais e aumentar a pressão antrópica sobre os ecossistemas nativos.

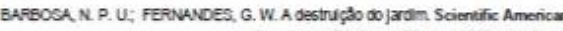
Bracil Ano 7, numero 60, dez: 2008 (acaptasos
Nesse contexto, para conciliar os interesses aparentem contraditórios entre o progresso social e urbano conservaçăo do meio ambiente, seria razoável

Q impedir a abertura e a pavimentaçāo de rodovias àreas rurais e em regiōes preservadas, pois a qualic de vida $e$ as tecnologias encontradas nos centros urb săo prescindiveis às populaçōes rurais.

- impedir a abertura e a pavimentaçăo de rodovias áreas rurais $e \mathrm{em}$ regiōes preservadas, promoven migração das populaçōes rurais para os centros urba onde a qualidade de vida é melhor

( $)$ permitir a abertura $\theta$ a pavimentação de rodovias ap: em àreas rurais produtivas, haja vista que nas de áreas o retorno financeiro necessärio para produzir melhoria na qualidade de vida da regiăo nä́o é garantic

() permitir a abertura $\theta$ a pavimentaçắo de rodovias, d permitir a abertura $e$ a pavimentaçáo de rodovias, de
que comprovada a sua real necessidade $\theta$ apo realizaçăo de estudos que demonstrem ser pos: contornar ou compensar seus impactos ambientais.

$\Theta$ permitir a abertura e a pavimentaçäo de rodovias. vista que os impactos ao meio ambiente săo temporári podem ser facilmente revertidos com as tecnolo existentes para recuperação de áreas degradadas.

(Fonte: ENEM 2009 - Caderno Azul)

A questão anterior deixa claro os interesses contraditórios existentes entre a mobilidade urbana e o progresso versus a necessidade de conservação ambiental, convidando o candidato a decidir sobre a solução mais assertiva que comtemple o interesse de diferentes grupos e se posicione frente a esse problema social. Por ser uma questão de múltipla escolha, ela deve ser razoavelmente delimitada de modo que apenas um dos itens possa ser considerado correto. Assim, como forma de conciliar os diversos interesses, a alternativa correta é a letra $D$ que acha valida a abertura de rodovias após estudo que comprove a real necessidade dela e que os impactos ambientais possam ser minimizados.

Reunindo todas as questões analisadas, referente a exigência ou não de posicionamento crítico frente a problemas sociais, obtivemos os seguintes resultados:

Gráfico 4 - Resultado quantitativo geral para a categoria 5.

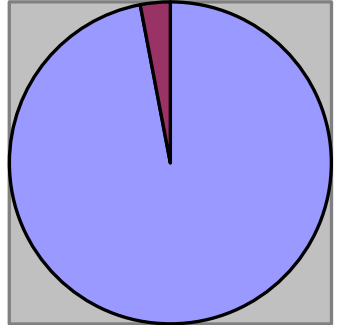


Na categoria 6 (articulação entre as disciplinas) buscou-se identificar de que maneira a Biologia se articula com outras disciplinas, isto é, se ela se aproxima mais de uma questão multidisciplinar com articulações sutis entre os campos do conhecimento ou de uma questão interdisciplinar em que o diálogo entre as disciplinas é maior e mais robusto ou ainda se não existe relação com outras disciplinas. Deste modo, em todos os anos analisados a questão que mostrou maior diálogo entre os campos do conhecimento, foi a questão 22 do ENEM de 2009, sendo classificada como interdisciplinar uma vez que nesta questão é necessário que o candidato mobilize seus conhecimentos sobre as áreas da Biologia, Química e Física.

Figura 12 - Questão A09AZ22 que representa a subcategoria "interdisciplinar".

\section{Questao 22}

Um medicamento, após ser ingerido, atinge a corrente sanguínea e espalha-se pelo organismo, mas, como suas moléculas "não sabem" onde é que está o problema, podem atuar em locais diferentes do local "alvo" e desencadear efeitos além daqueles desejados. Não seria perfeito se as moléculas dos medicamentos soubessen exatamente onde está o problema e fossem apenas até aquele local exercer sua ação? A técnica conhecida como iontoforese, indolor e não invasiva, promete isso. Como mostram as figuras, essa nova técnica baseia-se na aplicação de uma corrente elétrica de baixa intensidade sobre a pele do paciente, permitindo que fármacos permeiem membranas biológicas e alcancem a corrente sanguínea, sem passar pelo estômago. Muitos paciente relatam apenas um formigamento no local de aplicação. 0 objetivo da corrente elétrica é formar poros que permitam a passagem do fármaco de interesse. A corrente elétrica é distribuida por eletrodos, positivo e negativo, por meio de uma solução aplicada sobre a pele. Se a molécula do medicamento tiver carga elétrica positiva ou negativa, ao entrar em contato com o eletrodo de carga de mesmo sinal, ela será repelida e forçada a entrar na pele (eletrorrepulsão - A). Se for neutra, a molécula será forcada a entrar na pele juntamente com o fluxo de solvente fisiológico que se forma entre os eletrodos (eletrosmose - B)
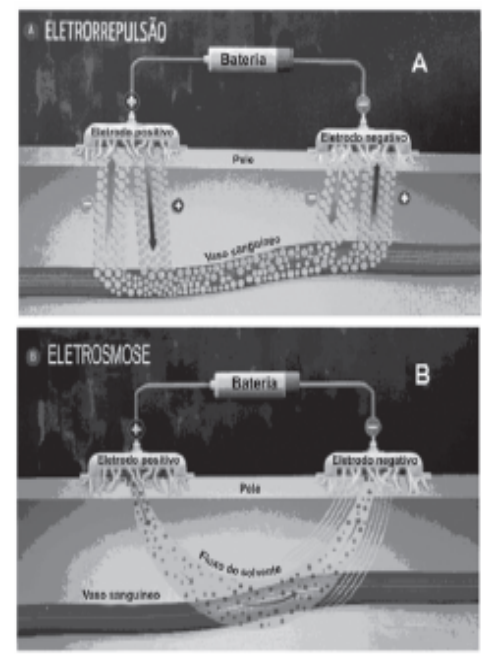

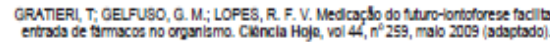

(Fonte: ENEM 2019 - Caderno Azul)

Na questão anterior, conforme aponta também Miranda et al. (2010) há a mobilização sobre os conhecimentos da Biologia, quando se fala sobre a distribuição dos fármacos através da corrente sanguínea, e dos conhecimentos da
De acordo com as informações contidas no texto e nas figuras, o uso da iontoforese introduzidos os eletrodos, rompendo o epitélio.

B aumenta o risco de estresse nos pacientes, causado pela aplicação da corrente elétrica.

Q inibe o mecanismo de ação dos medicamentos no tecido-alvo, pois estes passam a entrar por meio da pele.

D diminui o efeito colateral dos medicamentos, se comparados com aqueles em que a ingestão se faz por via oral.

a deve ser eficaz para medicamentos constituídos de moléculas polares e ineficaz, se essas forem apolares.
A provoca ferimento na pele do paciente ao serem 
Física, quando se mencionada a técnica de lontoforese. Além disso, é necessário também a mobilização de conhecimentos da área da química para se compreender que as moléculas dos fármacos podem apresentar carga positiva, negativa ou neutra.

Já a questão a seguir foi classificada na categoria 6.2 pois mostrou características de uma questão multidisciplinar.

Figura 13 - Questão A10AZ60 que representa a subcategoria "multidisciplinar".

Questão 60
A lavoura arrozeira na planície costeira da região sul
do Brasil comumente sofre perdas elevadas devido à
salinização da água de irrigação, que ocasiona prejuízos
diretos, como a redução de produção da lavoura.
Solos com processo de salinização avançado não são
indicados, por exemplo, para o cultivo de arroz. As
plantas retiram a água do solo quando as forças de
embebição dos tecidos das raízes são superiores às
forças com que a água é retida no solo.

WINKEL, H.L.TSCHIEEEL, M. Cultura do arroz: salinizacãa de solos em cultivos de arroz
Disponivel em: htp://agropage tripod.com/saliniza.hml. Acosso em: 25 jun. 2010 (adaptado).

A presença de sais na solução do solo faz com que seja dificultada a absorção de água pelas plantas, o que provoca o fenômeno conhecido por seca fisiológica, caracterizado pelo(a)

(A) aumento da salinidade, em que a água do solo atinge uma concentração de sais maior que a das células das raízes das plantas, impedindo, assim, que a água seja absorvida.

B aumento da salinidade, em que o solo atinge um nível muito baixo de água, e as plantas não têm força de sucção para absorver a água.

๑ diminuição da salinidade, que atinge um nível em que as plantas não têm força de sucção, fazendo com que a água não seja absorvida.

- aumento da salinidade, que atinge um nível em que as plantas têm muita sudação, não tendo força de sucção para superá-la.

๑ diminuição da salinidade, que atinge um nível em que as plantas ficam túrgidas e nẳo têm força de sudação para superá-la.

(Fonte: ENEM 2010 - Caderno Azul)

Na questão anterior há o objetivo de se integrar os conhecimentos da Biologia e da Química, no entanto, é possível se chegar a alternativa correta sem o conhecimento das duas áreas. A questão ainda pode ser utilizada de maneira disciplinar, pois ao manter suas características próprias, se aproxima mais dos conhecimentos biológicos.

Em contrapartida a questão 2 de 2009 (Figura 14), também classificada como multidisciplinar, apresenta uma proposta diferente.

Na questão anterior, conforme aponta também Miranda et al. (2010) há uma articulação muito simples entre as disciplinas uma vez que o conhecimento matemático é utilizado apenas para sistematizar um conhecimento biológico. 
Figura 14 - Questão A09AZ2 que representa a subcategoria "multidisciplinar".

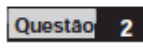

Analise a figura.

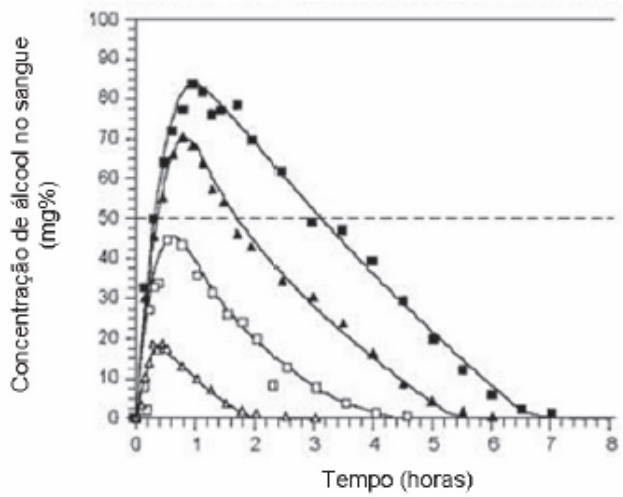

Disponivel em: http//www.alcoologia.net. Acesso em: 15 jul. 2009 (adaptado).

Supondo que seja necessário dar um título para essa figura, a alternativa que melhor traduziria o processo representado seria:

( Concentração média de álcool no sangue ao longo do dia.

๑ Variação da frequência da ingestão de álcool ao longo das horas.

C Concentração mínima de álcool no sangue a partir de diferentes dosagens.

- Estimativa de tempo necessário para metabolizar diferentes quantidades de álcool.

• Representação gráfica da distribuição de frequência de álcool em determinada hora do dia

(Fonte: ENEM 2009 - Caderno Azul)

Deste modo, para a categoria 6 em que se analisou as formas de articulação entre as disciplinas, obtivemos os seguintes resultados.

Gráfico 5 - Resultado quantitativo geral para a categoria 6.

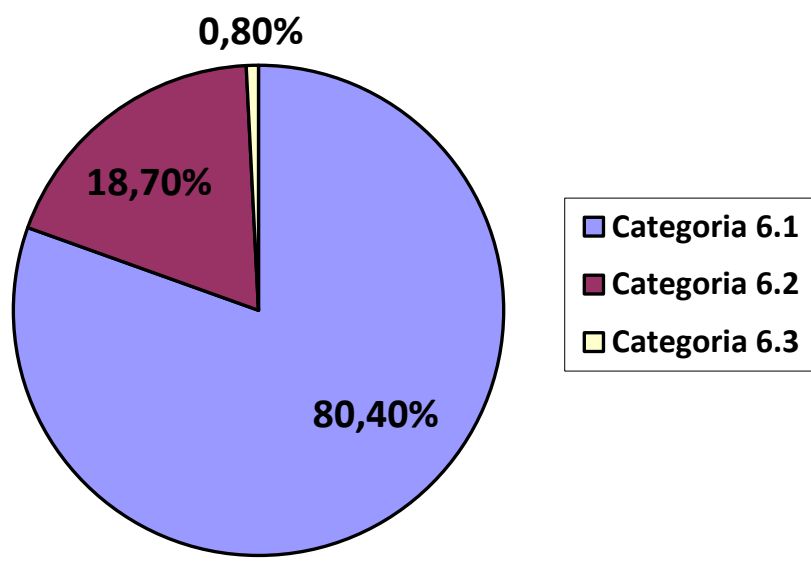

(Fonte: Dados da pesquisa)

Percebe- se, portanto, que a maioria das questões não apresentam relações entre a Biologia e outras disciplinas. Entre as questões que dialogam com outras disciplinas, a grande maioria pode ser classificada como multidisciplinar e apenas uma questão pode ser considerada de fato interdisciplinar. Pinheiro e Ostermann 
(2010), ao analisarem as questões de física do ENEM de 2009 também concluíram que, apesar da própria disposição da prova favorecer a interdisciplinaridade, poucas questões apresentam de fato a integração entre as disciplinas. Esse resultado era esperado devido à complexidade na elaboração de questões interdisciplinares, bem como o maior grau de dificuldade de resolução por parte dos candidatos. Por ser uma prova de avaliação em massa aplicada em todo o território nacional, as questões devem se manter em determinado grau de dificuldade de maneira que possa contemplar candidatos das diferentes regiões e de diferentes condições sociais, econômicas e culturais.

De maneira geral, concluímos que o ENEM representa um avanço em relação aos tradicionais vestibulares e que em suas questões podem ser encontradas características que vão de encontro a uma abordagem CTS. No entanto, ainda são necessárias mais alterações a fim de se explorar mais intensamente o potencial CTS das questões.

\section{CONSIDERAÇÕES FINAIS}

É necessário ressaltar que o ENEM utiliza apenas itens objetivos do tipo múltipla escolha. Esse tipo de item, conforme mencionado por documentos oficiais do Ministério da Educação, tem como vantagens a rapidez, a capacidade de abranger muitos conteúdos e a objetividade da correção, estando menos vulneráveis a erros de julgamento pelo corretor e sendo indicados para avaliação de grupos grandes (BRASIL, 2010). Dessa maneira, um ponto crucial para a elaboração da prova do ENEM é a objetividade, indispensável para a avaliação de massa e capazes de produzirem dados por meio de metodologia própria. Por esse motivo, esperávamos que algumas categorias fossem menos exploradas do que outras em decorrência da estruturação da prova e por ser feita em escala nacional. Nesse sentido, Sobrinho et al. (2013) apontam que é um desafio elaborar questões sociocientíficas em uma prova objetiva que necessita de uma única resposta.

A maioria das questões analisadas apresenta uma visão da ciência neutra, pois se trata de um exame que pretende e avaliar o conhecimento dos candidatos e para isso é necessário que ela seja o mais objetiva possível, não deixando margem a dúvidas ou discussões. Uma abordagem da ciência como construção humana, por ampliar muito o horizonte a ser discutido, se torna menos objetiva e envolvem opiniões. Já a ciência trabalhada de maneira neutra, se mostra muito objetiva, na qual alguns conceitos são cientificamente validados enquanto outros não, de forma que não abre margem para opiniões e discussões. Desta maneira, também é difícil se elaborar questões de múltipla escolha que consiga passar um olhar da ciência como construção humana. Acreditamos que esse tipo de abordagem seja mais facilmente utilizado em sala de aula, quando da discussão do conteúdo, pois é um momento propicio a discussão entre professores e alunos e de ampliação da visão sobre a ciência. Em contrapartida, utilizar uma abordagem da ciência como construção humana em itens de múltipla escolha para avaliações nacionais não parece ser o mais usual.

$\mathrm{Na}$ categoria 2, percebemos que apenas os aspectos técnicos da tecnologia são trabalhados e valorizados, enquanto os aspectos organizacionais e culturais são negligenciados. Esse tipo de abordagem vai de encontro com os cenários das aulas de ciências nas escolas, pois historicamente os aspectos técnicos são 
privilegiados e outros temas que perpassam esses conteúdos não são debatidos ou são pouco debatidos. Em contrapartida, de modo semelhante ao explanado para a questão anterior, se restringir ao conteúdo meramente técnico torna a questão mais objetiva, e, portanto, mais propicia a exames de massa. No entanto, acreditamos que é necessário que no contexto escolar outros aspectos referentes a tecnologia sejam considerados e debatidos, uma vez que são assuntos muito presentes no dia-a-dia do cidadão.

Em relação a categoria 4, o ENEM realmente vai ao encontro ao que é proposto uma vez que praticamente todas as questões são contextualizadas. Os elaboradores dos documentos oficiais do ENEM mencionam que a comunicação entre os diferentes componentes curriculares também propicia a contextualização, dessa forma, a categoria 4 (contextualização) e a categoria 6 (articulação entre as disciplinas) utilizadas no presente trabalho estão relacionadas (FERNANDES; MARQUES, 2012). Apesar da contextualização ser importante para o exame, o foco principal deve estar nas situações-problemas e nas competências (FERNANDES; MARQUES, 2012).

A contextualização é um diferencial importante em relação as questões tradicionais de vestibulares, em que na maioria das vezes, apresentavam questões curtas, não contextualizadas e objetivas (PINHEIRO; OSTERMANN, 2010). O ENEM por sua vez apresenta itens com texto bases, responsáveis pelo contexto, e questões maiores. No entanto, é desejável também que essa contextualização esteja bem desenvolvida no item, de forma que ela seja necessária para a resolução da situação-problema proposta, o que nem sempre ocorre nesse exame. Muitas vezes se observa que o contexto serve apenas como ilustração para a questão, não sendo necessária para a sua resolução, assim, apenas lendo o enunciado da questão e ignorando o texto-base o candidato é capaz de resolver o item. Desta maneira, esse tipo de contextualização não ajuda na resolução da questão e não traz consigo ganhos em relação a tomada de decisão ou desenvolvimento de competências. Além disso, questões nesses moldes podem favorecer os candidatos mais experientes que utilizam a estratégia de ler primeiramente o enunciado do item e identificar se é possível resolver a questão sem fazer a leitura do texto-base. Em uma prova longa como o ENEM, esse tipo de estratégia representam um ganho de tempo na resolução da prova e benefícios para os candidatos que adotam essa estratégia.

Concluímos que o ENEM apresenta questões voltadas para a abordagem CTS, mas que elas ocorrem em pequenas quantidades nos anos analisados. Também não foi verificado mudanças significativas no decorrer dos anos, no sentido de elaborar um exame mais voltado para a abordagem CTS. O ENEM, embora difere dos vestibulares tradicionais, ainda tem um longo caminho a percorrer no sentido de propor questões que se aproximem mais dos preceitos declarados em sua matriz de referência e que valorizem mais a abordagem CTS, sendo, portanto, mais significativo para o candidato. 


\title{
Survey and analysis of the science, technology and society approach in ENEM biology issues from 2009 to 2014
}

\begin{abstract}
In 2009, the new ENEM emerges and is one of the main evaluations in the Brazilian education scenario and is viewed as a regulator of the quality of basic education. The ENEM's official documents show that this examination is based on the concepts of skills and abilities, emphasizing, among other things, interdisciplinarity, contextualization and problems-situations. Therefore, the theoretical conception of ENEM aggress with a Science-Technology-Society approach (STS), which is essential for the formation of an active and participatory citizen. In this work we identify, categorize and analyze the STS approach expressed in ENEM Biology questions from 2009 to 2014. Following the methodology of Bardin, the questions were classified and analyzed. Although we conclude that the ENEM represents a breakthrough in relation to the traditional exam, additional modifications are still necessary so that its questions get closer to a STS approach.
\end{abstract}

KEYWORDS: ENEM. STS approach. Biology. 
${ }^{1}$ Competências são as modalidades estruturais da inteligência. Ações e operações que são utilizadas para estabelecer relações com e entre objetos, situações e fenômenos que se deseja conhecer (BRASIL, 2002).

${ }^{2}$ As habilidades decorrem das competências adquiridas e remete ao "saber fazer" (BRASIL, 2002).

\section{REFERÊNCIAS}

ALVES, A. Exame Nacional do Ensino Médio (Enem): fundamentação teóricometodológica. Apresentação. In: BRASIL. Ministério da Educação. Instituto Nacional de Estudos e Pesquisas Educacionais Anísio Teixeira. Brasília, 2005. p. $7-$ 9.

ANDRELLA, R.; DECONTO, D.C.S.; CAVALCANTI, C.J.H.; OSTERMANN, F. As relações entre Ciências, Tecnologia e Sociedade veiculadas pelo novo ENEM. In: VIII Encontro Nacional de Pesquisa em Educação em Ciências. Campinas. 2011.

AULER, D. Enfoque Ciência-Tecnologia-Sociedade: pressupostos para o contexto brasileiro. Ciência \& Ensino. Campinas, v. 1, n. especial, p. 01-20, 2007.

AULER, D. Interações entre Ciências-Tecnologia- Sociedade no Contexto da Formação de Professores de Ciências. Tese de Doutorado. Florianópolis: CED/UFSC, 2002.

BARDIN, L. (1977). Análise de Conteúdo. Lisboa: Edições 70, 2010.

BEBER, L B. C. Expectativas acerca do efeito indutor do novo ENEM: reorganizações curriculares na conquista da educação escolar de melhor qualidade. Dissertação de Mestrado. Rio Grande do Sul: Unijuí, 2012.

BRASIL. Instituto Nacional de Estudos e Pesquisas Educacionais Anísio Teixeira. Matriz de referência do Enem 2009. Brasília: MEC/INEP, 2009.

BRASIL. Instituto Nacional de Estudos e Pesquisas Educacionais Anísio Teixeira. Guia de elaboração e revisão de itens. Brasília, v. 1, 2010.

FERNANDES, C. S; MARQUES, C. A.; A contextualização do ensino de ciências: a voz de elaboradores de textos teóricos e metodológicos do exame nacional do ensino médio. Investigações em Ensino de Ciências. v.17(2), pp. 509-527, 2012. 
FREIRE, P. Pedagogia da Esperança: Um reencontro com a pedagogia do oprimido. Rio de Janeiro: Paz e Terra, 1992.

GALLAGHER, J.J. A broader base for Science Education. Science Education, 55, pp.329-338, 1971.

GOMES, C. M. A.; BORGES, O. O ENEM é uma avaliação educacional construtivista? Um estudo da validade do construto. Estudos em Avaliação Educacional, São Paulo, v. 20, n. 42, p. 73-88, jan./abr. 2009.

INSTITUTO Nacional de Estudos e Pesquisas Educacionais Anísio Teixeira. Exame Nacional do Ensino Médio (Enem): fundamentação teórico-metodológica. Brasília, 2005.

JALOTO, A.; MARTINS, I. Os sentidos de contextualização no ENEM: uma análise de trabalhos apresentados nas edições do ENPEC entre 2007 e 2011. In: IX ENPEC (IX Encontro Nacional de Pesquisa em Educação em Ciências). Águas de Lindoia, 2013.

MAIA, P. F.; JUSTI, R. Desenvolvimento de habilidades no ensino de ciências e o processo de avaliação: análise de coerência. Ciência e Educação, v. 14, n. 3, p. 431$50,2008$.

MACHADO, N. J. Interdisciplinaridade e contextualização. In: BRASIL. Ministério da Educação. Instituto Nacional de Estudos e Pesquisas Educacionais Anísio Teixeira. Exame Nacional do Ensino Médio (Enem): fundamentação teórico-metodológica. Brasília, 2005. p. 41-53.

MIRANDA, E. M.; ALVES, A. R.; MENTEN, M. L. M, FREITAS, D.; ZUIN, V. G.; PIERSON, A. H. C. ENEM 2009: articulações entre CTS, interdisciplinaridade e contextualização evidenciadas nas questões das Ciências da Natureza. In: VIII ENPEC (VII Encontro Nacional de Pesquisa em Educação em Ciências). Campinas, 2010.

PINHEIRO, N. C.; OSTERMANN, F. Uma análise comparativa das questões de Física no novo ENEM e em provas de vestibular no que se refere aos conceitos de interdisciplinaridade e contextualização. In: XII Encontro de Pesquisa em Ensino de Física, 2010, Águas de Lindóia. Anais do XII Encontro de Pesquisa em Ensino de Física, 2010.

RICARDO, E. C. Competências, interdisciplinaridade e contextualização: dos Parâmetros Curriculares Nacionais a uma compreensão para o ensino das 
Educação Científica e Tecnológica da Universidade Federal de Santa Catarina, 2005.

ROSA, S.E, AULER, D. Manifestações da suposta neutralidade da Ciência-Tecnologia em abordagem CTS. In: IX ENPEC (IX Encontro Nacional de Pesquisa em Educação em Ciências). Águas de Lindoia, 2013.

SANTOS, J.M.T. Exame nacional do ensino médio: entre a regulação da qualidade do ensino médio e o vestibular. Educar em Revista. v. 1, n. 40, p. 195-205. 2011.

SANTOS, W. L. P. 0 ensino de química para formar o cidadão: principais características e condições para a sua implantação na escola secundaria brasileira. 233f. Dissertação de Mestrado. Campinas: Faculdade de Educação, Universidade Estadual de Campinas, 1992.

SANTOS, W. L. P.; MORTIMER, E. F. Uma análise de pressupostos teóricos da abordagem C-T-S (Ciência - Tecnologia - Sociedade) no contexto da educação brasileira. Ensaio - Pesquisa em Educação em Ciências. v. 2, n. 2, 2002.

SOBRINHO, M. F; RAMOS, T. C.; SANTOS, W. L. P. Questões de Física no ENEM/2012 com caráter sociocientífico: um estudo do potencial argumentativo à luz do padrão Toulmin. In: IX ENPEC (IX Encontro Nacional de Pesquisa em Educação em Ciências). Águas de Lindoia, 2013.

SOBRINHO, M. F; SANTOS, W. L. P. Inserções da interdisciplinaridade e contextualização dos itens do ENEM/2013 com potencial ao enfoque CTS. Unipluri/versidad, v. 14, N.ㅇ 3, 2014.

STRIEDER, R.B. Abordagem CTS na Educação Científica no Brasil: Sentidos e Perspectivas. 2012. Tese de Doutorado. São Paulo: Instituto de Física e Faculdade de Educação de São Paulo, São Paulo, 2012.

VACCAREZZA, L. S. Ciência, tecnologia e sociedade: o estado da arte na América Latina. In: SANTOS, L.W et al. (ORG.). Ciência, tecnologia e sociedade: o desafio da interação. Londrina: IAPAR, 2004. 
Recebido: 2017-05-24

Aprovado: 2018-08-23

DOI: $10.3895 /$ rbect.v11n3.5922

Como citar: RAAD, R. V.; MATOS, S. A.; COUTINHO, F. A. Levantamento e análise da abordagem Ciência, Tecnologia e Sociedade nas questões de biologia do ENEM de 2009 a 2014. Revista Brasileira de Ensino de Ciência e Tecnologia, v. 11, n. 3, 2018. Disponível em: <https://periodicos.utfpr.edu.br/rbect/article/view/5922>. Acesso em: $\mathrm{xxx}$.

Correspondência: Raquel Viana Raad - raquelvrbio@gmail.com

Direito autoral: Este artigo está licenciado sob os termos da Licença Creative Commons-Atribuição 4.0 Internacional. 